\title{
Sustainable Syntheses and Sources of Nanomaterials for Microbial Fuel/Electrolysis Cell Applications: An Overview of Recent Progress
}

\author{
Domenico Frattini $^{1,2}{ }^{\mathbb{D}}$, Gopalu Karunakaran ${ }^{3, *} \mathbb{C}$, Eun-Bum Cho ${ }^{3} \mathbb{C}$ and Yongchai Kwon ${ }^{1,4, *}$ \\ 1 Graduate School of Energy and Environment, Seoul National University of Science and Technology (Seoultech), \\ 232 Gongneung-ro, Nowon-gu, Seoul 01811, Korea; domenico.frattini@seoultech.ac.kr \\ 2 Centre for Cooperative Research on Alternative Energies (CIC energiGUNE), Basque Research and \\ Technology Alliance (BRTA), Alava Technology Park, Albert Einstein 48, 01510 Vitoria-Gasteiz, Spain \\ 3 Biosensor Research Institute, Department of Fine Chemistry, Seoul National University of Science and \\ Technology (Seoultech), 232 Gongneung-ro, Nowon-gu, Seoul 01811, Korea; echo@seoultech.ac.kr \\ 4 Department of Chemical and Biomolecular Engineering, Seoul National University of Science and \\ Technology (Seoultech), 232 Gongneung-ro, Nowon-gu, Seoul 01811, Korea \\ * Correspondence: karunakarang5@seoultech.ac.kr (G.K.); kwony@seoultech.ac.kr (Y.K.)
}

check for updates

Citation: Frattini, D.; Karunakaran, G.; Cho, E.-B.; Kwon, Y. Sustainable

Syntheses and Sources of

Nanomaterials for Microbial

Fuel/Electrolysis Cell Applications: An Overview of Recent Progress. Processes 2021, 9, 1221. https:// doi.org/10.3390/pr9071221

Academic Editor: Mohd

Azlan Hussain

Received: 15 June 2021

Accepted: 12 July 2021

Published: 15 July 2021

Publisher's Note: MDPI stays neutral with regard to jurisdictional claims in published maps and institutional affiliations.

Copyright: (c) 2021 by the authors. Licensee MDPI, Basel, Switzerland. This article is an open access article distributed under the terms and conditions of the Creative Commons Attribution (CC BY) license (https:// creativecommons.org/licenses/by/ $4.0 /)$.

\begin{abstract}
The use of microbial fuel cells (MFCs) is quickly spreading in the fields of bioenergy generation and wastewater treatment, as well as in the biosynthesis of valuable compounds for microbial electrolysis cells (MECs). MFCs and MECs have not been able to penetrate the market as economic feasibility is lost when their performances are boosted by nanomaterials. The nanoparticles used to realize or decorate the components (electrodes or the membrane) have expensive processing, purification, and raw resource costs. In recent decades, many studies have approached the problem of finding green synthesis routes and cheap sources for the most common nanoparticles employed in MFCs and MECs. These nanoparticles are essentially made of carbon, noble metals, and nonnoble metals, together with a few other few doping elements. In this review, the most recent findings regarding the sustainable preparation of nanoparticles, in terms of syntheses and sources, are collected, commented, and proposed for applications in MFC and MEC devices. The use of naturally occurring, recycled, and alternative raw materials for nanoparticle synthesis is showcased in detail here. Several examples of how these naturally derived or sustainable nanoparticles have been employed in microbial devices are also examined. The results demonstrate that this approach is valuable and could represent a solid alternative to the expensive use of commercial nanoparticles.
\end{abstract}

Keywords: carbon nanomaterials; green syntheses; metal nanoparticles; microbial fuel cells; microbial electrolysis cells

\section{Introduction}

In everyday life, energy plays an important part in sustaining processes required for life. Due to increased energy demands, researchers have focused on the research and development of low-cost and long-lasting energy sources [1]. In such efforts, microbial fuel cells (MFCs) potentially represent the best source of low-cost and eco-friendly (often referred to as "green") energy production, where they operate by converting organic waste into electricity.

Over the last few decades, the development of microbial electrochemical technologies has been very active and productive and is mainly represented by MFCs and microbial electrolysis cells (MECs) [2,3]. These devices can use the organic matter in residual biomass or wastewater to either produce usable electricity (via MFCs) [4] or biosynthesize hydrogen [5] and other valuable chemicals (via MECs). Although the peculiar advantages of these devices are well-known and appreciated by scientists, market penetration and diffusion at the industrial level are inhibited by the problems related to high capital costs, increases in scale, 
the multiplication/miniaturization approach [6] to maintain a suitable power density, COD (Chemical oxygen demand) removal rate, and value-added chemical production. Roughly, regardless of MFCs or MECs, the cost allocations for a device are represented by the anode, cathode, proton exchange membrane (PEM), reactor case, current collectors, and other costs (e.g., pumping, control systems, and assembly). The performance of MFC and MEC materials is dependent on several factors, such as the $\mathrm{pH}[7,8]$, temperature, cell design, surface structure [9], microbial inoculation [10,11], solution conductivity/nutrient concentration [12,13], and the efficiency of the charge transfer to/from electrodes. These issues are not exclusively related to MFCs and MECs, but also to other bioelectrochemical devices like microorganism-based sensors [14]. In a series of recent focused reviews, the emerging niche for the advantageous application of conductive polymers in biosensors and biofuel cells has been discussed [15], pointing out that these polymers possess biocompatibility, a fast transduction mechanism, and versatile synthesis processes. Moreover, it was found that they can greatly improve the electron transfer mechanism toward direct pathways [16], as shown in Figure 1. This is because conducting polymers such as polypyrrole [17] and MXenes [18] can be easily nanostructured and doped to obtain functional materials.

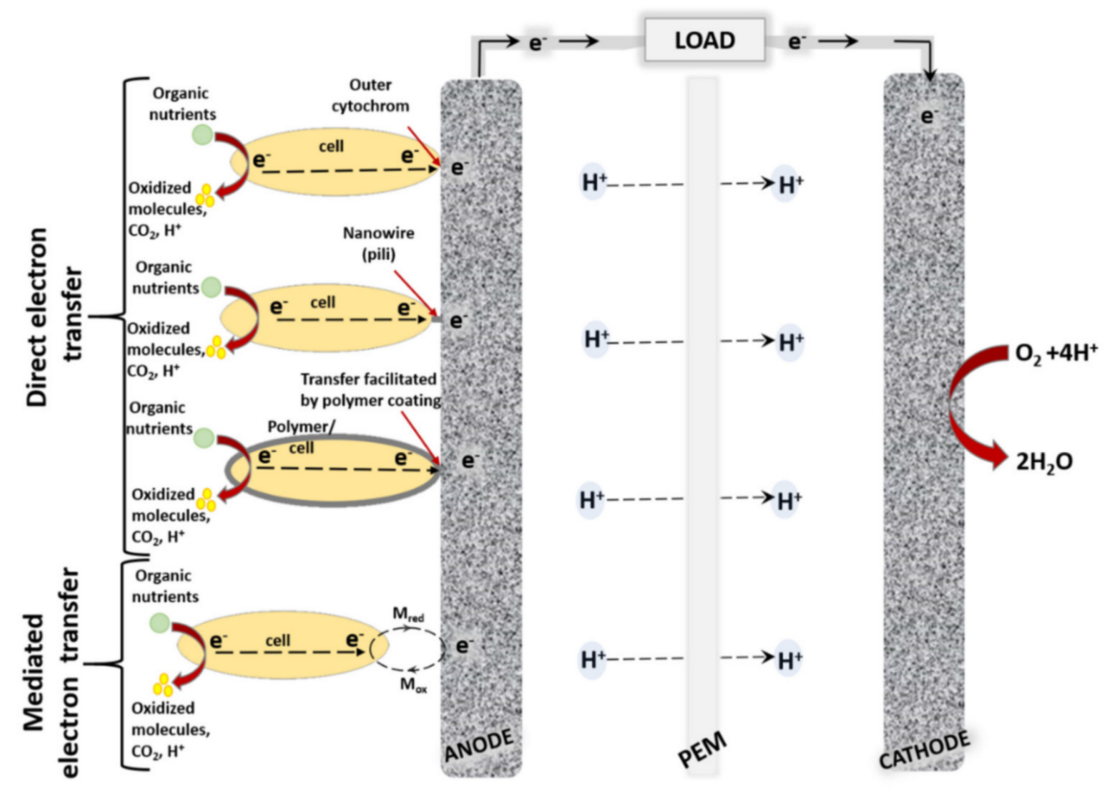

Figure 1. Direct and mediated electron transfer mechanism in bioelectrochemical devices and the facilitation offered by conducting polymers. Reproduced from [14] under a CC BY 4.0 license.

Large-scale and real-time applications of these devices are limited, for example, to small and wearable devices [19], whereas, for larger systems, one of the limits is the insufficient cost-effectiveness of electrode materials with low toxicity in neutral or nearneutral $\mathrm{pH}$ media. It has been reported in the literature that, for MFCs, the membrane and the cathode account for $85 \%$ of the total costs [20], while they should be around $30-40 \%$ of the total cost in order to be economically feasible. For MECs, the anode and the current collectors represent $94 \%$ of costs [21], while the cost should be less than $10-20 \%$ of the total cost to make a MEC device practical for use. Recently, regarding the membrane or separator, a successful trend has been substitute Nafion with porous ceramic materials [22-25], which have a lower cost, longer lifetime, and resistance to biofouling, whereas, for the electrode, the insufficient cost-effectiveness presents a more difficult challenge to overcome.

This is because electrodes usually entail the insertion of nanoscale and nanoengineered materials that can boost the performance [26], but also increase the fabrication costs. Furthermore, the use of nanomaterials may not always result in the desired boosting effect [27], particularly for cathodes [28], where the increase in performance can be quite modest in practical use. The main electrode materials for MFCs are carbon-based, but there are huge 
differences in price between nanostructured and non-nanostructured materials [29]. Furthermore, MFC cathode catalysts are usually noble metals, i.e., Pt-based, whereas the use of non-Pt catalysts has been a longstanding challenge in reducing costs [30,31]. Recently, noble metals have been used to modify anode materials to impart an electrical bridging effect to improve electron transfer [32,33]. Non-noble metal nanoparticles will be widely used in the near future, thus creating a very interesting research niche. If this barrier is overcome, microbial electrochemical devices can potentially generate more profits and revenues than traditional wastewater treatments [34].

Reducing electrode material costs is critical for microbial electrochemical technologies to gain market attractiveness. The cost abatement needed to become feasible for use can only be achieved by excluding the use of noble metals and scavenging raw carbon materials from secondary or natural sources and then transforming them into performant nanostructured materials using green synthesis routes that are cheap and effective. Due to these driving reasons, and additionally to overcome the problems arising from toxicity and low performance, green synthesis approaches are developing are attractive solutions in this regard.

Two steps must be met for such an approach to be successful. The first step is to choose and control the synthesis routes that will convert a renewable, natural, and abundant source into a nanomaterial [35]. The second step is to use the eco-friendly synthesized materials as components in MFCs and MECs in order to demonstrate the real feasibility and performance that can be achieved with the simultaneous cost of these raw materials potentially being close to zero. As a result, this overview is divided into two main parts: The first part of the overview deals with some interesting examples of how eco-friendly syntheses and natural and recycled sources can produce nanostructured/nanosized materials, with the second part highlighting and discussing the performances of nanomaterials obtained from green, sustainable, or recycled sources in MFCs and MECs.

\section{The Green and Sustainable Approach for Nanoparticles Production}

\subsection{Potential Renewable and Sustainable Raw Sources for Different Kinds of Nanoparticles}

Even though different technologies may improve nanoparticle synthesis, nature itself is an especially prominent nanotechnologist, providing many naturally occurring nanoparticles in different processes, such as volcanic eruptions, iceberg sedimentation, umber, natural surface water, seawater, mineral wells, ore deposits, and particulates.

In volcanic eruptions, the occurrence of silica $\left(\mathrm{SiO}_{2}\right)$ nanoparticles has been extensively reported and such nanoparticles are well-known for their use in food additives, cellular imaging, and antireflection coating applications [36]. Iceberg sediments are also a good source of iron oxide $\left(\mathrm{Fe}_{3} \mathrm{O}_{4}\right)$ nanoparticles, which are used in hyperthermia, medical diagnostics, biosensors, and drug delivery applications [37]. Umber is also a good source for manganese oxide $\left(\mathrm{MnO}_{2}\right)$ nanoparticles, which are used for catalysis, remediation, and imaging. Natural surface water contains a large reservoir of different nanoparticles, such as calcium carbonate $\left(\mathrm{CaCO}_{3}\right)$, silicates $\left(\mathrm{SiO}_{2}\right)$, and alumina $\left(\mathrm{Al}_{2} \mathrm{O}_{3}\right)$ [38]. Furthermore, seawater, mineral wells, ore deposits, and particulate represent potential reservoirs of silver $(\mathrm{Ag})$, gold $(\mathrm{Au})$, carbon $(\mathrm{C})$, and sulfur $(\mathrm{S})$ nanoparticles [39-42]. Some recent research performed by different researchers has shown how these natural renewable sources can be effectively utilized to produce different nanoparticles, such as metal titanates $\left(\mathrm{FeTiO}_{3}\right)$ from ilmenite sand, alumina $\left(\mathrm{Al}_{2} \mathrm{O}_{3}\right)$ nanoparticles from bauxite, $\mathrm{TiO}_{2}$ nanoparticles from natural ilmenite, and iron oxide nanoparticles $\left(\mathrm{Fe}_{3} \mathrm{O}_{4}\right)$ from ironstone [43-46]. Iron oxide nanoparticles obtained from ironstone have been found to be in the order of 10 to $50 \mathrm{~nm}$ in size when obtained by a simple precipitation method using hydrochloric acid and an ammonia solution [43]. $\mathrm{TiO}_{2}$ nanoparticles have been synthesized from raw ilmenite in multiple steps. Firstly, raw ilmenite has been treated with concentrated sulfuric acid and then treated with ferric sulfate to obtain titanium sulfate, which is converted to titanium hydroxide using ammonium hydroxide. The resulting titanium hydroxide has been sintered at $300{ }^{\circ} \mathrm{C}$ to obtain $\mathrm{TiO}_{2}$ nanoparticles with a size of about $50 \mathrm{~nm}$ [44]. 
Furthermore, raw bauxite has been used to obtain alumina $\left(\mathrm{Al}_{2} \mathrm{O}_{3}\right)$ nanoparticles via multiple steps, such as washing with sodium hydroxide to convert it into Bayer liquor, where the Bayer liquor was then treated with sulfuric acid to obtain an aluminum hydroxide precipitate. The obtained precipitate was calcined at $500^{\circ} \mathrm{C}$ to obtain spherical particles that were of the order of $50 \mathrm{~nm}$ in size on average [45]. $\mathrm{FeTiO}_{3}$ nanoparticles (or metal titanates in general) can be synthesized by acid extraction followed by a precipitation method, and the resulting nanoparticles have been found to have a size between 50 to $100 \mathrm{~nm}$ [46]. It must be mentioned here that although these sources feature abundant amounts of minerals or mineral residues, the chemicals used in the extraction processes are harmful and are certainly not eco-friendly. This represents the aspect that must be improved when using natural sources for nanoparticle production.

The other primary class of materials used as electrode materials for MFCs and MECs is nanocarbons. While the sources of the previously mentioned nanoparticles are sometimes specialized inorganic residues, minerals, and sediments, carbon can be easily obtained from everyday organic biomass in the form of waste. Biochar is a solid residue that is produced with the high-temperature pyrolysis of any kind of organic biomass, and originally the term referred to the product used in agronomy and soil applications as a fertilizer and/or for biocompatible discharge/landfill with organic matter. Pyrolysis, along with other thermic procedures conceptually derived from it, is the primary method for converting biomass into biochar and involves prolonged heat treatment in an inert or oxygen-deficient atmosphere with a determined heating rate, dwell temperature and time, and additionally the separation of gaseous, liquid, and solid products. Such pyrolysis techniques have a background that arises from traditional industrial fossil coal processing techniques. This matter has a long story and has already been an object of concern in extensive studies, reviews, and books, like [47-49], and is still widely investigated nowadays.

When applied to microbial electrochemical cells, although mainly MFCs, biochar is receiving remarkable interest. This is because an engineered thermal process can provide conductive carbonaceous porous materials that are nanostructured and feature traces of other mineral elements when using practically any sort of waste biomass. This class of materials can be associated to the family of heteroatom-doped carbons because, as a result of the pyrolysis, the inorganic atoms (e.g., Fe, N, P, S, etc.) from trace minerals in the raw biomass turn into defective active sites in the carbon structure. In the literature, it is possible to find many exotic examples of waste biomass employed as raw material for pyrolysis and biochar production. Here, some examples of biochar explicitly tailored for microbial systems applications are reported (Table 1).

Table 1. Examples of biochar production from biomass when designed for MFC or MEC application.

\begin{tabular}{|c|c|c|c|c|c|c|}
\hline N. & Source Material & $\begin{array}{l}\text { Surface Area } \\
\left(\mathrm{m}^{2} \mathrm{~g}^{-1}\right)\end{array}$ & $\begin{array}{l}\text { Avg. Pore Size } \\
(\mathrm{nm})\end{array}$ & $\begin{array}{c}\text { Process } \\
\text { Conditions }\end{array}$ & Trace Elements & Ref. \\
\hline 1 & $\begin{array}{l}\text { Water hyacinth } \\
\text { (Eichhornia } \\
\text { crassipes) }\end{array}$ & $25.9(\mathrm{BET}) *$ & $5.6(\mathrm{BET})$ & $\begin{array}{l}\text { Washing, sunlight drying, } \\
\text { drying at } 80^{\circ} \mathrm{C} \text { for } 1 \mathrm{~h}, \\
\text { pyrolysis at } 900^{\circ} \mathrm{C} \text { for } 2 \mathrm{~h} \\
\text { at a rate of } 25^{\circ} \mathrm{C} \mathrm{min}-1\end{array}$ & $\begin{array}{l}\mathrm{Al}, \mathrm{Mg}, \mathrm{Si}, \mathrm{P}, \mathrm{S}, \mathrm{O} \\
\mathrm{K}, \mathrm{Ca}, \mathrm{Fe}, \mathrm{Cu}, \mathrm{Zn} \\
\quad(\mathrm{EDS})^{*}\end{array}$ & {$[50]$} \\
\hline 2 & Bananas & $\begin{array}{c}105.1-172.3 \\
(\mathrm{BET})\end{array}$ & - & $\begin{array}{l}\text { Hydrothermal treatment at } \\
180^{\circ} \mathrm{C} \text { for } 12 \mathrm{~h} \text {, filtration, } \\
\text { washing, drying at } 60^{\circ} \mathrm{C} \text {, } \\
\text { pyrolysis at } 900^{\circ} \mathrm{C} \text { for } 2 \mathrm{~h} \\
\text { in Ar, washing, drying at } \\
100^{\circ} \mathrm{C} \text { for } 12 \mathrm{~h} \text {, activation } \\
\text { with } \mathrm{KOH}\end{array}$ & $\mathrm{O}, \mathrm{N}$ (EDS) & [51] \\
\hline 3 & Alfalfa leaves & 148-883 (BET) & - & $\begin{array}{l}\text { Pyrolysis at } 250{ }^{\circ} \mathrm{C} \text { for } 2 \mathrm{~h} \\
\text { in } \mathrm{N}_{2}, \mathrm{FeCl}_{3} / \mathrm{KOH} / \mathrm{ZnCl}_{2} \\
\text { activation, pyrolysis at } \\
900{ }^{\circ} \mathrm{C} \text { for } 2 \mathrm{~h} \text { in } \mathrm{N}_{2}\end{array}$ & $\begin{array}{c}\mathrm{O}, \mathrm{N}, \mathrm{P}, \mathrm{S}, \mathrm{Fe} \\
(\mathrm{EDS})\end{array}$ & [52] \\
\hline
\end{tabular}


Table 1. Cont.

\begin{tabular}{|c|c|c|c|c|c|c|}
\hline N. & Source Material & $\begin{array}{l}\text { Surface Area } \\
\qquad\left(\mathrm{m}^{2} \mathrm{~g}^{-1}\right)\end{array}$ & $\begin{array}{l}\text { Avg. Pore Size } \\
(\mathrm{nm})\end{array}$ & $\begin{array}{l}\text { Process } \\
\text { Conditions }\end{array}$ & Trace Elements & Ref. \\
\hline 4 & Corncob & $68.5-655.9(\mathrm{CV}) *$ & - & $\begin{array}{l}\text { Sunlight drying for } 5 \text { days } \\
\text { and pyrolysis at } 750{ }^{\circ} \mathrm{C} \text { for } \\
\qquad 2 \mathrm{~h} \text { in } \mathrm{N}_{2}\end{array}$ & $\mathrm{O}, \mathrm{K}, \mathrm{N}, \mathrm{P}(\mathrm{EDS})$ & [53] \\
\hline 5 & $\begin{array}{l}\text { Green algae } \\
\text { (Spirogyra) }\end{array}$ & 258 (BET) & $\begin{array}{l}4(\mathrm{BET}) \\
50-200 \mu \mathrm{m} \\
(\mathrm{SEM})\end{array}$ & $\begin{array}{l}\text { Washing, shaping, vacuum } \\
\text { filtration, freeze-drying, } \\
\text { and pyrolysis at } 1100^{\circ} \mathrm{C} \\
\text { for } 2 \mathrm{~h} \text { in } \mathrm{N}_{2}\end{array}$ & - & [54] \\
\hline 6 & Pinewood lumber & 42.4 (BET) & - & $\begin{array}{l}\text { Gasification at } 1000^{\circ} \mathrm{C} \text { at a } \\
\text { rate of } 17^{\circ} \mathrm{C} \mathrm{min}-1 \text { in air, } \\
\text { sonication } 30 \mathrm{~min} \text {, stirring } \\
\text { at } 80^{\circ} \mathrm{C} \text { for } 2 \mathrm{~h} \text { in } 3 \mathrm{M} \\
\mathrm{KOH} \text {, filtering, washing, } \\
\text { vacuum drying at } 50^{\circ} \mathrm{C} \text { for } \\
3 \mathrm{~h} \text {, functionalization } \\
\text { with } \mathrm{Mn}\end{array}$ & $\begin{array}{l}\mathrm{Al}, \mathrm{Ca}, \mathrm{K}, \mathrm{Mg}, \\
\mathrm{Mn}, \mathrm{P}, \mathrm{Si} \\
\mathrm{Ti}(\mathrm{ICP})^{*}\end{array}$ & [55] \\
\hline 7 & Lotus leaves & 611-909 (BET) & 0.49-1.23 (BET) & $\begin{array}{l}\text { Washing, ultrasonication } \\
\text { for } 2 \mathrm{~h} \text {, drying at } 40^{\circ} \mathrm{C} \text { for } \\
12 \mathrm{~h} \text {, hydrothermal } \\
\text { treatment with } \\
\mathrm{ZnCl}_{2} /\left(\mathrm{NH}_{4}\right)_{2} \mathrm{SO}_{4} \text { at } \\
160{ }^{\circ} \mathrm{C} \text { for } 2 \mathrm{~h} \text {, drying } \\
60^{\circ} \mathrm{C} \text { for } 24 \mathrm{~h} \text {, pyrolysis at } \\
1000{ }^{\circ} \mathrm{C} \text { for } 2 \mathrm{~h} \text { in } \mathrm{N}_{2} \\
\text { washing, drying at } 60^{\circ} \mathrm{C} \\
\text { for } 24 \mathrm{~h}\end{array}$ & $\begin{array}{l}\mathrm{Ca}, \mathrm{N}, \mathrm{O} \\
\mathrm{S}(\mathrm{XPS}) *\end{array}$ & [56] \\
\hline 8 & Sewage Sludge & 44 (BET) & 0.8-8.6 (BET) & $\begin{array}{l}\text { Drying, pyrolysis at } 900{ }^{\circ} \mathrm{C} \\
\text { for } 2 \mathrm{~h} \text { at a rate of } \\
5^{\circ} \mathrm{C} \mathrm{min}^{-1} \text { in } \mathrm{N}_{2}\end{array}$ & $\mathrm{~N}, \mathrm{O}, \mathrm{Fe}(\mathrm{XPS})$ & [57] \\
\hline 9 & Coffee waste & 3.5-428 (BET) & 7.9-23.2 (BET) & $\begin{array}{l}\text { Washing, filtering, drying, } \\
\text { activation in } \mathrm{KOH} \text { for } 24 \mathrm{~h} \text {, } \\
\text { pyrolysis at } 900^{\circ} \mathrm{C} \text { for } 1 \mathrm{~h} \\
\text { in } \mathrm{N}_{2} \text {, washing, drying for } \\
24 \mathrm{~h}\end{array}$ & - & {$[58]$} \\
\hline 10 & Kapok tree fibres & - & $\begin{array}{l}10-20 \mu \mathrm{m} \\
(\mathrm{SEM})^{*}\end{array}$ & $\begin{array}{l}\text { Washing, shaping, } \\
\text { pyrolysis at } 1100{ }^{\circ} \mathrm{C} \text { for } 2 \mathrm{~h} \\
\text { at a rate of } 30 / 200{ }^{\circ} \mathrm{C} \mathrm{h}^{-1} \\
\text { in } 95 \% \mathrm{Ar} \text { and } 5 \% \mathrm{H}_{2} \\
\text { washing, filtering }\end{array}$ & - & [59] \\
\hline 11 & Eggplant & 637-1181 (BET) & - & $\begin{array}{c}\text { Peeling, shredding, } \\
\text { washing, drying at } 100^{\circ} \mathrm{C} \\
\text { for } 8 \mathrm{~h} \text {, activation in } \\
\mathrm{K}_{3}\left[\mathrm{Fe}\left(\mathrm{C}_{2} \mathrm{O}_{4}\right)_{3}\right], \text { drying, } \\
\text { pyrolysis at } 800{ }^{\circ} \mathrm{C} \text { for } 1 \mathrm{~h} \\
\text { at a rate of } 5^{\circ} \mathrm{C} \mathrm{min}{ }^{-1} \mathrm{~N}_{2}, \\
\text { washing in } 2 \mathrm{M} \text { of } \mathrm{HCl} \text {, } \\
\text { washing, drying at } 70^{\circ} \mathrm{C} \\
\text { for } 8 \mathrm{~h}\end{array}$ & N, O (EDS) & {$[60]$} \\
\hline
\end{tabular}


Table 1. Cont.

\begin{tabular}{|c|c|c|c|c|c|c|}
\hline 12 & Rice husk & $\begin{array}{l}\text { 1164-1809 } \\
\text { (BET) }\end{array}$ & 12.4-23.1 (BET) & $\begin{array}{l}\text { Grinding, washing, drying } \\
\text { at } 105^{\circ} \mathrm{C} \text { for } 12 \mathrm{~h} \text {, washing } \\
\text { in } 98-54 \% \text { wt } \mathrm{H}_{2} \mathrm{SO}_{4} \text { at } \\
55^{\circ} \mathrm{C} \text {, filtration, washing, } \\
\text { drying at } 60^{\circ} \mathrm{C} \text { for } 2 \mathrm{~h} \text {, } \\
\text { drying at } 95^{\circ} \mathrm{C} \text { for } 6 \mathrm{~h} \text {, } \\
\text { washing, drying at } 120^{\circ} \mathrm{C} \\
\text { for } 12 \mathrm{~h} \text {, pyrolysis at } \\
500{ }^{\circ} \mathrm{C} \text { for } 0.5 \mathrm{~h} \text { in } \mathrm{N}_{2} \text {, } \\
\text { activation with } \\
\mathrm{NaOH} / \mathrm{KOH} \text {, pyrolysis at } \\
400{ }^{\circ} \mathrm{C} \text { for } 0.5 \mathrm{~h} \text { and then } \\
800{ }^{\circ} \mathrm{C} \text { for } 1 \mathrm{~h}\end{array}$ & - & [61] \\
\hline 13 & Mixed microalgae & $\begin{array}{c}21 \\
(\mathrm{BET})\end{array}$ & - & $\begin{array}{l}\text { Filtering, washing with } \\
\mathrm{HCl} \text { at } 1 \mathrm{mM} \text {, } \\
\text { centrifugation, drying at } \\
60{ }^{\circ} \mathrm{C} \text {, pyrolysis at } 400^{\circ} \mathrm{C} \\
\text { for } 2 \mathrm{~h} \text { at a rate of } 10^{\circ} \mathrm{C} \\
\mathrm{min}^{-1} \text {, washing, drying at } \\
60{ }^{\circ} \mathrm{C} \text {, pyrolysis at } 900^{\circ} \mathrm{C} \\
\text { for } 1 \mathrm{~h} \text { at a rate of } \\
5^{\circ} \mathrm{C} \text { min }{ }^{-1} \text { in Ar, washing, } \\
\text { drying at } 60^{\circ} \mathrm{C} \text { overnight }\end{array}$ & N, O, P (XPS) & [62] \\
\hline 14 & Watermelon rind & $\begin{array}{c}78-659 \\
(\mathrm{CV})\end{array}$ & - & $\begin{array}{l}\text { Washing, drying at } 40^{\circ} \mathrm{C} \\
\text { for } 72 \mathrm{~h} \text {, sonication in } 1 \mathrm{M} \\
\text { of } \mathrm{HCl} \text { for } 5 \mathrm{~h} \text {, filtering, } \\
\text { washing, drying at } 85^{\circ} \mathrm{C} \\
\text { for } 12 \mathrm{~h} \text {, pyrolysis at } \\
700{ }^{\circ} \mathrm{C} \text { for } 2 \mathrm{~h} \text { at a rate of } \\
5^{\circ} \mathrm{C} \text { min }^{-1} \text { in } \mathrm{N}_{2}\end{array}$ & N, O (XPS, EDS) & [63] \\
\hline 15 & $\begin{array}{c}\text { Sewage } \\
\text { sludge/coconut } \\
\text { shell }\end{array}$ & 16-54 (BET) & - & $\begin{array}{l}\text { Grinding, shaping, drying } \\
\text { at } 50{ }^{\circ} \mathrm{C} \text {, pyrolysis at } \\
900{ }^{\circ} \mathrm{C} \text { for } 2 \mathrm{~h} \text { at a rate of } \\
5^{\circ} \mathrm{C} \text { min }^{-1} \text { in } \mathrm{N}_{2}\end{array}$ & $\begin{array}{c}\mathrm{O}, \mathrm{N}, \mathrm{Fe}, \mathrm{P}(\mathrm{XPS}, \\
\mathrm{EDS})\end{array}$ & [64] \\
\hline 16 & $\begin{array}{l}\text { Sludge from } \\
\text { wastewater } \\
\text { treatment }\end{array}$ & 41.8 (BET) & - & $\begin{array}{c}\text { Drying at } 105^{\circ} \mathrm{C} \text {, pyrolysis } \\
\text { at } 500^{\circ} \mathrm{C} \text { for } 1.5 \mathrm{~h} \text { at a rate } \\
\text { of } 10^{\circ} \mathrm{C} \mathrm{min}-1 \text { in } \mathrm{N}_{2}, \mathrm{HCl} \\
\text { activation, drying at } \\
105^{\circ} \mathrm{C}\end{array}$ & $\begin{array}{l}\mathrm{N}, \mathrm{S}, \mathrm{Si}, \mathrm{Fe}, \mathrm{Al} \text {, } \\
\mathrm{Ca}, \mathrm{Mg}, \mathrm{K}, \mathrm{Na} \\
\text { (elemental } \\
\text { analysis) }\end{array}$ & [65] \\
\hline
\end{tabular}

* BET: Brunauer-Emmett-Teller; EDS: energy dispersive X-ray spectroscopy; CV: cyclic voltammetry; ICP: inductively-coupled plasma; XPS: X-ray photoelectron spectroscopy; SEM: scanning electron microscopy.

From Table 1, it is possible to observe that there are a plethora of recipes to obtain various forms of biochar from different biomasses, thus present several options for pre/post washing and drying of the fresh biomass, along with the use of a hydrothermal or alkaline solution for activation of the dried mass before the pyrolysis step. Some papers suggest that different parts of the same biomass, e.g., corncobs, sunflowers, woody sticks, etc., can lead to various biochar forms with different activities. This is an interesting perspective, but the real occurrence of a qualitative and quantitative remarkable variance of activity should be investigated more. What is well assessed in the various recipes is the effect of the pyrolysis temperature [66], which typically ranges between 750-950 ${ }^{\circ} \mathrm{C}$, with $\mathrm{N}_{2}$ and Ar as inert gases, an alkaline activation step, abundant washing steps to eliminate mineral ashes to reduce trace elements essential to $\mathrm{N}, \mathrm{O}$, and $\mathrm{Fe}$, and the relevant volume variation as the final amount of obtained product is small and depends on the weight percentage of carbon and other inorganic elements present in the dried biomass. This can be evaluated by performing simple proximate/ultimate elemental analyses to provide an idea of the yield 
of the process (which unfortunately has not always been reported in prior papers). This factor is important in determining process feasibility, as high yields may be associated with biomass that has a high content of carbon and is more easily processed, whereas low yields could be associated to waste biomass with a high volatile matter content, thus requiring large biomass volumes to be processed to obtain the same amount of biochar, consequently reducing the disposal volume required in landfills, although gas emissions could increase, and as such this presents a challenging trade-off. A good strategy is to add supporting biomass to increase the carbon content of the final biochar [64].

\subsection{Green Routes for the Synthesis of Nanoparticles}

Generally, nanoparticles are produced using harmful chemicals and highly sophisticated devices [67]. This could lead to the residual presence of chemicals in the final product and also increases the cost of production. To overcome such issues, green syntheses represent the best routes for the synthesis of nanoparticles and are typically relatively cheap and free from the use of harmful chemicals [68]. Recently, different biological components have been considered in order to elucidate the best components for the synthesis of different nanoparticle classes. The major biological components include marine organisms (green algae, brown algae, and seaweeds), micro-organisms, and plants (leaves, flowers, and fruits extracts) [69-73], as depicted in Figure 2.

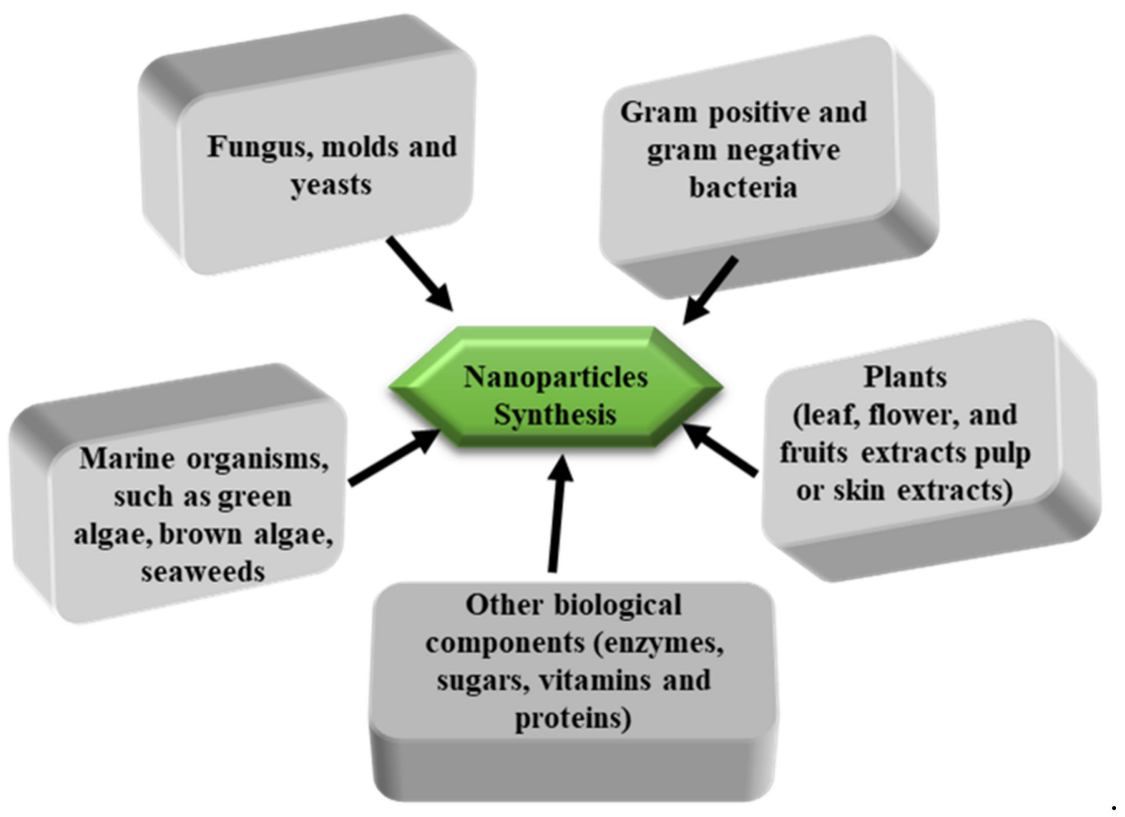

Figure 2. The major components used in the green synthesis of nanoparticles.

The synthesis of different metal and metal oxide nanoparticles by using some of the biological components mentioned above, from different sources, is represented in Table 2.

Generally, all the biosynthesis procedures are very simple. The methods of the aforementioned examples for synthesis generally consist of a few relatively simple steps. In general, when considering plant material as the biological source, plant material extracts are mixed with a precursor solution and kept for reaction from about 24 to $48 \mathrm{~h}$ to obtain a precipitate [84-89]. Plant extracts contain alkaloids, flavonoids, and other biological components which convert precursors into metal hydroxides or oxides. The obtained hydroxides are dried to obtain metal nanoparticles. The same procedure is followed for all the biological materials in biosynthesis after the stripping of extracts from them. 
Table 2. Some representative examples of different metal and metal oxide nanoparticles synthesized from bacteria, fungi, and plants.

\begin{tabular}{|c|c|c|c|c|c|c|}
\hline N. & Source Material & Nanoparticle & $\begin{array}{l}\text { Size } \\
(\mathrm{nm})\end{array}$ & Shape & $\begin{array}{l}\text { Purity } \\
(\%)\end{array}$ & Ref. \\
\hline 1 & Bacterium (Bacillus cereus) & $\mathrm{Ag}$ & $20-40$ & Spherical & 80 & [74] \\
\hline 2 & $\begin{array}{c}\text { Bacterium } \\
\text { (Desulfovvibrio desulfuricans) }\end{array}$ & $\mathrm{Au}$ & $5-50$ & $\begin{array}{l}\text { Nanorods or } \\
\text { nanoprisms }\end{array}$ & 80 & [75] \\
\hline 3 & $\begin{array}{c}\text { Bacterium } \\
\text { (Aquaspirillum magnetotacticum) }\end{array}$ & $\mathrm{Fe}_{3} \mathrm{O}_{4}$ & 10 & Octahedral prism & 70 & [76] \\
\hline 4 & Bacterium (Shewanella oneidensis) & $\mathrm{UO}_{2}$ & - & - & - & [77] \\
\hline 5 & Bacterium (E. coli) & $\mathrm{CdS}$ & 2.9 & Spherical & 100 & [78] \\
\hline 6 & Fungus (Rhizopus nigricans) & $\mathrm{Ag}$ & $13-74$ & Spherical & 100 & [79] \\
\hline 7 & Fungus (Verticillium luteoalbum) & $\mathrm{Au}$ & $\sim 100$ & $\begin{array}{l}\text { Spherical, triangular, } \\
\text { hexagonal }\end{array}$ & - & [80] \\
\hline 8 & Fungus (Fusarium oxysporum) & $\begin{array}{l}\text { Au-Ag } \\
\text { alloy }\end{array}$ & $8-141$ & Spherical & 98 & [81] \\
\hline 9 & Fungus (Aspergillus terreus) & $\mathrm{ZnO}$ & 8.2 & Spherical & 100 & [82] \\
\hline 10 & Fungus (Aspergillus flavus TFR7) & $\mathrm{TiO}_{2}$ & $12-15$ & Spherical & 80 & [83] \\
\hline 11 & Plant (Acalypha indica) & $\mathrm{Ag}$ & $20-30$ & Spherical & 80 & [84] \\
\hline 12 & Plant (Avena sativa) & $\mathrm{Au}$ & $25-85$ & $\begin{array}{l}\text { Spherical, triangular, } \\
\text { hexagonal }\end{array}$ & 78 & [85] \\
\hline 13 & Plant (Gardenia jasminoides Ellis) & $\mathrm{Pd}$ & $3-5$ & $\begin{array}{l}\text { Spherical, rod and } \\
\text { three-dimensional } \\
\text { polyhedral }\end{array}$ & 80 & [86] \\
\hline 14 & Plant (Medicago sativa) & $\mathrm{FeO}$ & $1-10$ & Spherical & - & [87] \\
\hline 15 & Plant (Sedum alfredii Hance) & $\mathrm{ZnO}$ & 53.7 & Spherical & - & [88] \\
\hline 16 & Plant (Aloe barbadensis Miller) & $\mathrm{In}_{2} \mathrm{O}_{3}$ & $5-50$ & Spherical & - & [89] \\
\hline
\end{tabular}

The biosynthesis of nanoparticles utilizing bacteria can be performed in two major ways, where the first is intracellularly mediated synthesis and the second is extracellularly mediated synthesis. For example, the intracellularly mediated synthesis of AgNPs using Bacillus cereus was investigated in [74]. In this work, $1 \mathrm{~g}$ of bacterial biomass was mixed with a silver nitrate solution and incubated for $120 \mathrm{~h}$, leading to the formation of AgNPs. In another method, Desulfovibrio desulfuricans was found to precipitate gold nanoparticles over its cellular membrane surface [76]. Magnetic $\mathrm{Fe}_{3} \mathrm{O}_{4}$ nanoparticles can be synthesized inside the cells of Aquaspirillum magnetotacticum by just providing the necessary precursor nutrients, where the bacteria then act as nanoparticle factories [76]. Similarly, an extracellular synthesis of nanoparticles was reported to produce $\mathrm{UO}_{2}$ nanoparticles using Shewanella oneidensis [77]. Furthermore, fungal extracellular extracts are also often utilized for the synthesis of nanoparticles. For example, Rhizopus nigricans was utilized to synthesize Ag nanoparticles with a resulting size range of 13-74 $\mathrm{nm}$ [79]. Verticillium luteoalbum fungal extracellular extracts have also been found to produce gold nanoparticles in the order of $100 \mathrm{~nm}$ in size when simply mixing with an auric chloride solution [79].

A recent emerging niche is the microbially assisted synthesis of conducting polymers, mainly polypyrrole, which sufficiently interacts with cell walls to improve charge transfer [90]. It well-known that cell wall proteins do act as the main actors for exoelectrogenesis in microorganisms [91], but the direct transfer of electrons to an electrode surface needs a boost to become more efficient. Andriukonis et al. [92] and Ramanavicius et al. [93] have recently demonstrated that it is possible to polymerize pyrrole to obtain polypyrrole (PPy) via S. Cerevisiae yeast cells. The polymerization exploits the redox ability of the yeast 
strain and the redox cycling of $\left.\left[\mathrm{Fe}(\mathrm{CN})_{6}\right]^{3-} /\left[\mathrm{Fe}(\mathrm{CN})_{6}\right]^{4-}\right]$. The improved quantification methodology that was exposed was able to analyze the changes in mechanical properties of the cell walls and the biocompatibility of PPy. Later, it was confirmed that these in situ modifications of the cell wall by the conducting polymer improved the direct charge transfer $[16,90]$ at the nanoscale level. In another work, Streptomyces ssp. bacteria were used for a totally natural and green synthesis of hollow PPy microspheres [94]. It was reported that no organic solvents and additives were used, and that the time needed to observe the sphere formation was 10 days. An environmentally friendly PPy form conjugated with a microorganism was obtained by a green method using Aspergillus niger, [95] a fungi that can release glucose oxidase and initiate PPy formation via an enzymatic reaction, as shown in Figure 3.

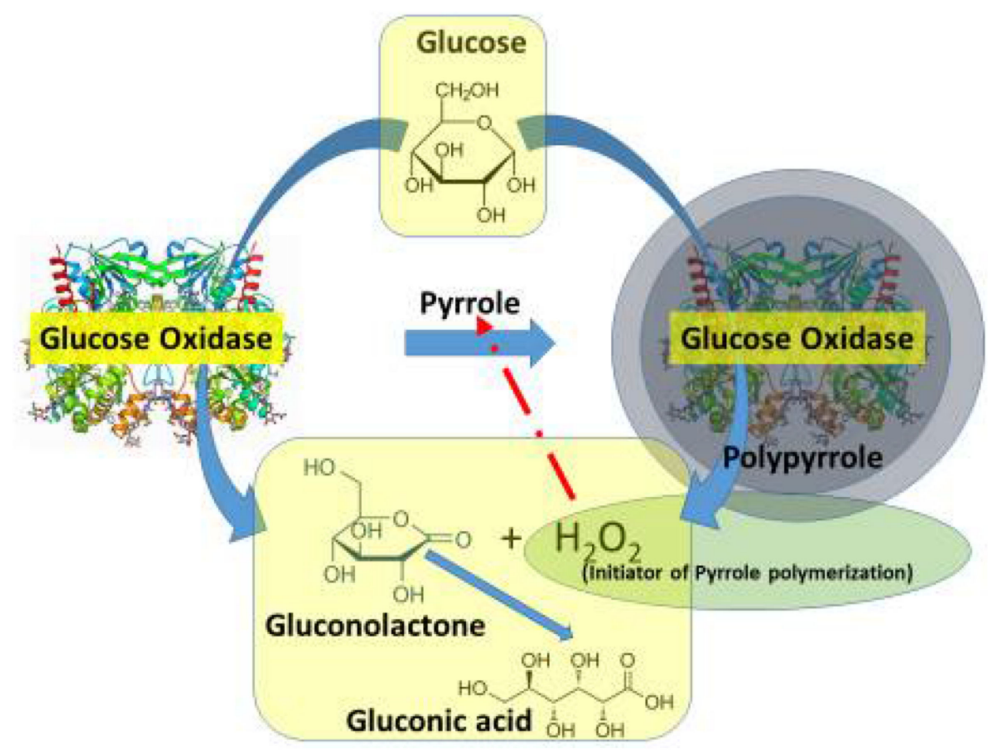

Figure 3. Biopolymerization of PPy in the presence of glucose oxidase, hydrogen peroxide, and glucose. Reproduced from [15] under a CC BY 4.0 license.

The authors compared this method with the chemical polymerization method and reported similar electrochemical properties for the obtained PPy chains. A similar result was obtained by the same group [96] when using a white-rot fungal strain from Trametes ssp., where the method was based on laccase enzyme release. In both cases, successful biopolymerization depended on the optimal concentration of the initiating enzyme, $\mathrm{pH}$, and surrounding environment. Cultures with sufficient intracellular space provided the best PPy cell wall conjugate quality.

Several green synthesis methods are available for the production of a wide range of nanoparticles; however, there are also several limitations with the use of these green processes. The first major challenge is product recovery, which is critical to reduce impurities [86]. The second major challenge is size control, where there is a knowledge gap in the exact mechanisms of various synthesis procedures, as well as the correlations with particle size, which is still being discovered [87]. The third major challenge is the time-consuming nature of green synthesis, which depends on the specific bacteria and materials used [88].

\subsection{Other Sustainable Unconventional Sources for Synthesis of Nanoparticles}

Based on a recent environment survey program conducted by the United Nations, it was reported that around 11.2 billion tons of waste is produced every year, which leads to serious environmental pollution that is toxic to human health [97]. The majority of produced waste is classified as electronic waste (electronic boards, circuit boards, copper cables, etc.) and industrial waste (wastewater, rubber tires, batteries, etc.) [98]. These wastes can be converted into useful nanomaterials by using ad hoc recovery processes in 
order to support the sustainable production of metal nanoparticles and, at the same time, the recycling and smart disposal of huge amounts of waste (Figure 4).

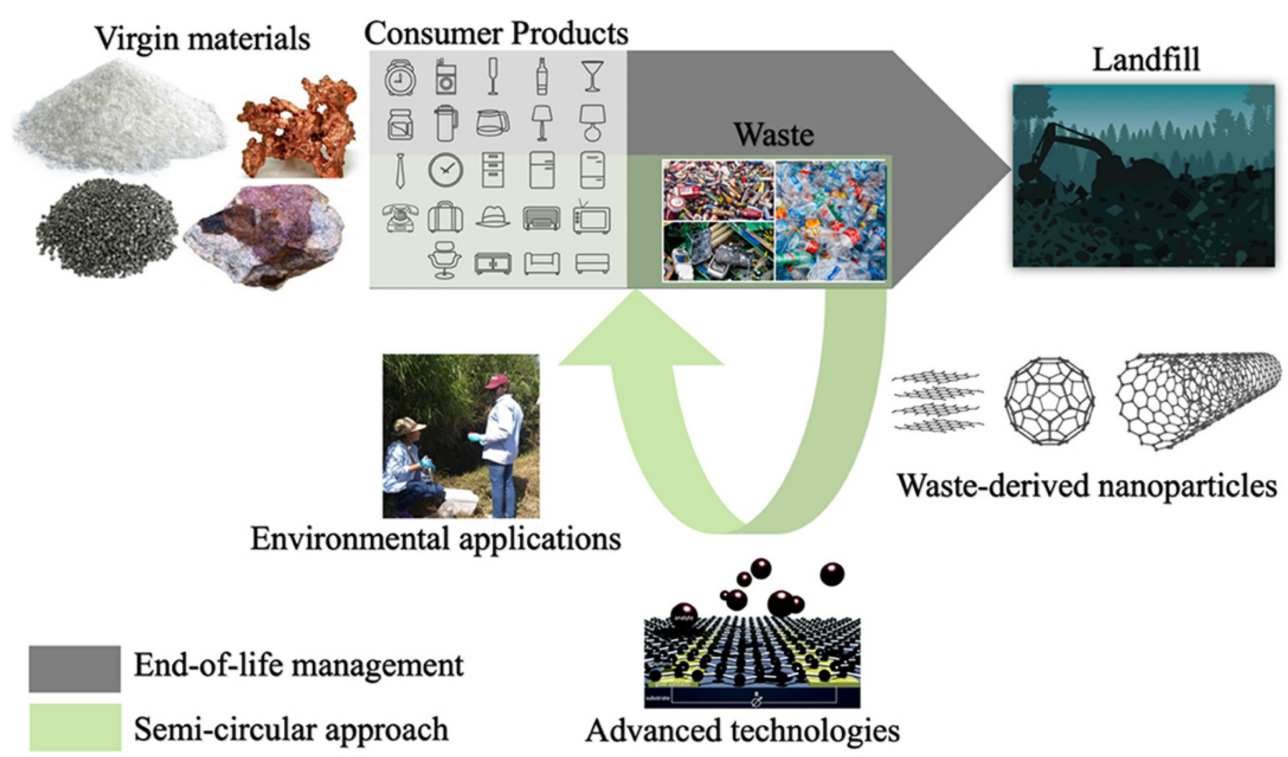

Figure 4. Conceptualization of recovery from electronic and domestic waste products as an alternative source of nanomaterials. Reproduced from [98] under a CC BY 4.0 license.

$\mathrm{Cu}_{2} \mathrm{O}$ can be synthesized from discarded printed circuit boards using PVP as a stabilizer in an electrokinetic process. The prepared nanoparticles have been found to have an average size of 5 to $40 \mathrm{~nm}$ [99]. Cu nanoparticles with a particle size of about $100 \mathrm{~nm}$ with cylindrical and/or spherical morphologies have been obtained from the recovery of automobile residues [100]. Cu nanoparticles with a spherical size of $20-50 \mathrm{~nm}$ have also been synthesized from discarded circuit boards through a microemulsion process [101]. Copper-tin (Cu-Sn) nanoparticles have been synthesized using old computer motherboards with resulting particle sizes of about $500 \mathrm{~nm}$ [102]. The possibility to use electronic waste as a source of metal nanoparticles is very attractive due to the high available volume of electronic waste that is regularly produced, but the effective introduction of this practice is severely limited by the low demand for nanoparticles in commercial use, such as in MFCs (which is not a mature and widely commercialized technology) or other devices, as well as the high costs of the recovery processes. Hence, a clean and economically feasible process is required that can convert these waste products into more sustainable value-added materials.

Another large share of waste with high re-utilization potential is represented by plastics, metals, and batteries. Some studies have investigated such utilization for years to recover various metals and metal oxides as particles or nanoparticles. Most recently, copper, silver, and copper/silver nanoparticles of a $50-80 \mathrm{~nm}$ size were synthesized utilizing metalized acrylonitrile butadiene styrene (ABS) plastic waste [103]. Nanocrystalline $\gamma$ - and $\alpha$-alumina nanoparticles of about 36 to $200 \mathrm{~nm}$ in size were synthesized using aluminium foil waste by a co-precipitation method [104]. Furthermore, nanosized $\alpha-\mathrm{Fe}_{2} \mathrm{O}_{3}$ particles with sizes ranging from 22 to $86 \mathrm{~nm}$ have been synthesized using ferrous sulfate waste obtained from the titanium industry [105]. Lead oxide nanoparticles of about $200 \mathrm{~nm}$ in size have been obtained from battery anode waste via a thermal evaporation method [106]. $\mathrm{ZnO}$ nanoparticles of about 100 to $300 \mathrm{~nm}$ in size have also been produced from zinc manganese battery waste by a vacuum evaporation method [107]. The sustainability of all of these processes relies upon the use of secondary raw materials and the production of waste originating from high-impact sectors like metallurgy, batteries, and plastics. The development, efficiency, and penetration of these technologies needs to be pursued in order to increase economic feasibility and profitability. 


\section{The Use of Green and Sustainable Nanoparticles and Materials in MFCs and MECs}

Due to advancements in nanoscience and nanotechnology, different classes of nanomaterials have been synthesized for MFCs and MECs. The major broad categories of nanomaterials include metal oxide and metal-based materials, carbon-sourced nanomaterials, and conjugated or composite materials.

In this section, these nanomaterials, which have been obtained from green and sustainable processes/raw sources to the maximum extent possible, are showcased and considered in terms of their application in electrodes for MFCs and MECs. Conjugated or composite materials are not treated separately here but are instead included in the first two main classes because it is difficult to find real green and sustainable examples.

Works where green and sustainable nanoparticles have been synthesized, characterized, and employed in MFCs/MECs have been carried out, although sometimes the whole approach could not be completely green and sustainable in all of the required steps; however, the mentioned classes of nanomaterials and their impacts on device operations are reported in the context of the vision of substituting non-green nanoparticles (e.g., available as/or synthesized from commercial chemicals) with nanoparticles of the same kind, except obtained from green and sustainable processes as described above.

As the absolute values of power density or methane/hydrogen yields are dependent also on the substrate, inoculum, media composition, and cell architecture, which each may differ from article to article, what more important is a relative boost in performance for each condition between a device with the use of a nanomaterial in contrast to a device without one.

\subsection{Metal Oxide and Metal-Based Materials}

Metal oxides and metal nanomaterials have a high capacity to easily interact with the biological components, and, due to this, they can easily support electron transport towards electrodes. Electron transport is a key component for improving the efficiency of MFCs, especially on the anode side in order to achieve direct electron transport (DET) due to the intimate electrical bridging effect that can be obtained by stacking the carbon anode support, metal nanoparticles, and grown biofilm on top [32,108,109]. It is true that transition metals and transition metal oxides have a good and recognized catalytic activity [110] for the ORR (in MFCs) [111] and OER/HER (in MECs) [112], but this activity is limited in microbial devices by the temperature and $\mathrm{pH}$, whereas the electrical bridging effect is not, showing a similar effect for bacteria with different DET characteristics [113]. Recent research by Wu et al. [114] showed that gold nanoparticles with S. oneidensis MR-1 bacteria could be very effective, potentially generating a power density of about $178.34 \pm 4.79 \mathrm{~mW} \cdot \mathrm{m}^{-2}$, which represents a $56.11 \%$ greater performance than that of the control cells. Another study of the biosynthesis of $\mathrm{Pt} / \mathrm{Pd}$ bimetallic nanoparticles obtained by $E$. coli was also found to be very effective for expressing microbial NP biointerfaces for ORR, but the approach was not tested for MFC applications [115]. Saravanakumar et al. have shown that the effectiveness of $\mathrm{Au}$ and Ag nanoparticles obtained from Trichoderma sp. is effected for catalysis in MFCs under the aid of anaerobic conditions [116]. They have shown that the highest current extracted by the biosynthesized material was $342.80 \mathrm{~mA}$. Plant-mediated (Amaranthus dubius) synthesis of iron oxide nanoparticles was found to be very effective in the MFC and showed a greater resulting power density of $145.5 \mathrm{~mW} \cdot \mathrm{m}^{-2}$ when compared to the control cell, which was deficient in nanoparticles [117]. Eucalyptus leaves were also used for the production of zerovalent iron nanoparticles so that they could be used for MFC applications [118]. The obtained results proved that the obtained zerovalent iron nanoparticles greatly improved the MFC performance. Citrobacter sp.-mediated synthesis of Pd nanoparticles has been shown to be very effective for MFC applications [119], where a higher power density of about $539.3 \mathrm{~mW} \cdot \mathrm{m}^{-3}$ was achieved. In another study by Tahernia et al., biogenic Pd nanoparticles were synthesized by using $S$. oneidensis MR-1, which was very effective and increased the performance by up to 75\% [120]. Karim et al. showed that biogenic $\mathrm{Au}$ nanoparticles are also very effective for improving the performance of MFCs [121]; 
however, not all metal nanoparticles have the same effect as an electrical bridge in MFC anodes. It was reported in [122] that the highest power density in MFCs with a metal NP-decorated carbon anode was obtained with Ni nanoparticles rather than Au or Pt. This is potentially a great result that is worth of further investigation and development, as noble or precious metals could be efficiently substituted and cheaper metals might be preferred.

An interesting comparative list of precious/non-precious metal/metal oxide nanomaterials used in MFCs is briefly reported in Table 3. The green or sustainable origins of the nanomaterials are also indicated.

Table 3. Metal and metal oxide nanomaterials used in MFCs and their relative performances.

\begin{tabular}{|c|c|c|c|c|c|c|c|}
\hline N. & Nanomaterial & $\begin{array}{c}\text { Green/Sustainable } \\
(\mathrm{Y} / \mathrm{N})\end{array}$ & MFC Type & Component & 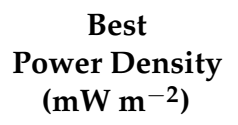 & $\begin{array}{c}\text { Control } \\
\text { Power Density } \\
\left(\mathrm{mW} \mathrm{m} \mathrm{m}^{-2}\right)\end{array}$ & Ref. \\
\hline 1 & $\begin{array}{l}\text { Pd NPs on } \\
\text { carbon cloth }\end{array}$ & $\mathrm{Y}$ & $\begin{array}{c}\text { Dual } \\
\text { chamber }\end{array}$ & Anode & 605 & 534 & [123] \\
\hline 2 & W/Co scraps & $\mathrm{Y}$ & $\begin{array}{c}\text { Dual } \\
\text { chamber }\end{array}$ & $\begin{array}{l}\text { Cathode } \\
\text { catalyst }\end{array}$ & $36 \mathrm{~W} \mathrm{~m}^{-3}$ & $3 \mathrm{~W} \mathrm{~m}^{-3}$ & [124] \\
\hline 3 & $\begin{array}{l}\text { Pd NPs on } \\
\text { carbon cloth }\end{array}$ & $\mathrm{Y}$ & $\begin{array}{c}\text { Dual } \\
\text { chamber }\end{array}$ & Anode & $824 \pm 36$ & \multirow{3}{*}{$680 \pm 28$} & \multirow{3}{*}{ [125] } \\
\hline 4 & $\begin{array}{l}\mathrm{MnO}_{2} \mathrm{NPs} \\
\text { on carbon } \\
\text { cloth }\end{array}$ & $\mathrm{N}$ & $\begin{array}{c}\text { Dual } \\
\text { chamber }\end{array}$ & Anode & $782 \pm 37$ & & \\
\hline 5 & $\begin{array}{l}\mathrm{Fe}_{3} \mathrm{O}_{4} \mathrm{NPs} \\
\text { on carbon } \\
\text { cloth }\end{array}$ & $\mathrm{N}$ & $\begin{array}{c}\text { Dual } \\
\text { chamber }\end{array}$ & Anode & $728 \pm 33$ & & \\
\hline 6 & Fe nanorods & $\mathrm{N}$ & $\begin{array}{c}\text { Dual } \\
\text { chamber }\end{array}$ & $\begin{array}{l}\text { Cathode } \\
\text { catalyst }\end{array}$ & $66.4 \mathrm{~mW} \mathrm{~m}^{-3}$ & $10.6 \mathrm{~mW} \mathrm{~m}^{-3}$ & [126] \\
\hline 7 & $\begin{array}{c}\mathrm{V}_{2} \mathrm{O}_{5} \\
\text { nanorods }\end{array}$ & $\mathrm{N}$ & $\begin{array}{l}\text { Single } \\
\text { chamber }\end{array}$ & $\begin{array}{l}\text { Cathode } \\
\text { catalyst }\end{array}$ & $1073 \pm 18$ & $2067 \pm 25$ & [127] \\
\hline 8 & $\begin{array}{l}\text { Au NPs on } \\
\text { carbon paper }\end{array}$ & $\mathrm{N}$ & $\begin{array}{c}\text { Dual } \\
\text { chamber }\end{array}$ & Anode & 346 & 174 & [128] \\
\hline 9 & $\begin{array}{c}\mathrm{MnO}_{\mathrm{x}} \\
\text { nanorods }\end{array}$ & $\mathrm{N}$ & $\begin{array}{l}\text { Single } \\
\text { chamber }\end{array}$ & $\begin{array}{l}\text { Cathode } \\
\text { catalyst }\end{array}$ & $772.8 \mathrm{~mW} \mathrm{~m}^{-3}$ & $236.7 \mathrm{~mW} \mathrm{~m}^{-3}$ & [129] \\
\hline 10 & $\begin{array}{c}\mathrm{WO}_{3} \mathrm{NPs} \text { on } \\
\text { carbon felt }\end{array}$ & $\mathrm{N}$ & $\begin{array}{l}\text { Single } \\
\text { chamber }\end{array}$ & Anode & 1280 & 490 & [130] \\
\hline
\end{tabular}

From this table and the previously described works, it is possible to conclude that inserting metal or metal oxide nanoparticles in MFCs can effectively increase the resulting performance (except for the singular case of $\mathrm{V}_{2} \mathrm{O}_{5}$ nanorods in Table 3). The absolute electricity generation depends on the specific substrate, cell design, and operating conditions, but improvements can be obtained if either the nanomaterial is used as an anode decoration or as a cathode catalyst. For example, it is well-known that the extent of the improvement for NP anode decoration is greatly dependent on the size and shape [131], rather than NP loading, as it happens for cathodes. In Table 3, it was intentionally shown that the ratio between recent studies using/non-using green and sustainable NPs is still low and that non-precious metal/metal oxide NPs can compete with $\mathrm{Au}, \mathrm{Pd}$, and Pt NPs (Pt-based electrodes are often used as controls, where they are hence represented appropriately in the power density of control column of Table 3).

Conjugated or composite materials have also been shown to improve the performance of microbial electrochemical devices nowadays, which has led to advancement in this field with the aim of designing new materials [132]. Such aims have often been based on composite (metals/oxides/carbon-based) or conjugated (polymers, layer-by-layer structures) materials, mainly to exploit the interactions between carbons, polymers, and the particular 
organism [133]. Qiao et al. developed mesoporous $\mathrm{TiO}_{2} /$ polyaniline composites and used them as anode materials in E. coli-based MFCs [134]. The MFC demonstrated a two-fold increase in the power density $\left(1495 \mathrm{~mW} \cdot \mathrm{m}^{-2}\right)$. Ma et al. showed that graphitized carbon and iron oxide nanocomposites are better cathode materials for improving the performance of MFCs [135]. Improved efficiency and higher stability were achieved after performance studies. Di Palma et al. showed that polyethersulfone $/ \mathrm{Fe}_{3} \mathrm{O}_{4}$ nanocomposites can be an excellent membrane for MFCs [136]. These works are reported as examples as the metal oxide NPs that have been mentioned can be easily prepared in more than one of the green and sustainable synthesis routes detailed above.

A considerable amount of literature can be found regarding metal NPs employed as cathode catalysts in MECs for hydrogen production. For example, the use of Pd NPs, both in traditionally or bio-synthesized forms, has been reported since a decade ago $[137,138]$. Even a non-precious metal-based catalysts such as Fe@C and derivates have been used in a MEC for hydrogen production [139], but the production was lower than that obtained with Pt-based catalysts, although the Fe-based catalyst was very cheap; however, since then, the challenges are still the maximization of hydrogen production, optimizing catalyst activity, and elucidating economic feasibility. The development of non-precious metal/metal oxide nanocatalysts, as well as the adoption of green syntheses and the use of sustainable sources, will help to overcome these existing challenges.

Briefly, some recent advances are reported here. Kim et al. [140] demonstrated an interesting hydrogen production of $0.95-1.55 \mathrm{~m}^{3} \mathrm{H}_{2} \mathrm{~m}^{-3} \mathrm{~d}^{-1}$ from Makgeolli wastewater in a single chamber MEC without a membrane when using non-precious $\mathrm{Cu}_{2} \mathrm{O}$ and $\mathrm{MoS}_{2}$ NPs as cathode catalysts. In another interesting comparative work [141], several metal NP were loaded on carbon felt cathode with a hot-pressed membrane in a single chamber MEC using acetate as substrate. The results showed that when $\mathrm{Pt} / \mathrm{C}, \mathrm{PtNi} / \mathrm{C}$, and $\mathrm{Ni} / \mathrm{C}$ cathode MECs were operated at the same low applied voltage of $0.4 \mathrm{~V}$, hydrogen production was more or less the same $\left(0.064-0.068 \mathrm{~m}^{3} \mathrm{H}_{2} \mathrm{~m}^{-3} \mathrm{~d}^{-1}\right)$, suggesting that, in these operating conditions, non-precious metal NPs can substitute Pt; however, the catalysts were prepared traditionally in both works. Looking at recent biogenic metal NPs, Wang et al. [142] investigated and compared Pd NPs deposited in situ on a carbon cloth cathode via an electrochemical or bio-assisted (Shewanella oneidensis MR-1) process. Under an applied voltage of $0.8 \mathrm{~V}$, the biogenic Pd NPs produced $0.0618 \mathrm{~m}^{3} \mathrm{H}_{2} \mathrm{~m}^{-3} \mathrm{~d}^{-1}$ of hydrogen, while the non-biogenic Pd NPs were limited to $0.0385 \mathrm{~m}^{3} \mathrm{H}_{2} \mathrm{~m}^{-3} \mathrm{~d}^{-1}$. The authors suggested the addition of Nafion as a binder to strengthen the bond between the carbon fibres and the biogenic Pd NPs as, in the long term, the adherence and durability of electrochemically deposited Pd NPs is better as a result; however, it should not be forgotten that some precious metal NPs, like Ag, have a non-negligible antimicrobial effect and not all bacteria can tolerate such metals in the same way [143]. Conversely, some non-precious metal/metal oxide NPs, like magnetite, can improve and accelerate electrochemical reactions in MEC bioelectrodes [144]. In a stimulating work, Yuan et al. [145] demonstrated the possibility to prepare a "multi-catalyst" including several elements (i.e., C, O, S, P, Cr, Ni, Fe, Cu) distributed at the nanoscale by simply thermally treating an electroplating sludge, i.e., a hazardous waste that is very difficult to dispose of. Another interesting catalyst (unfortunately prepared with standard chemicals and methods) proposed recently is a $\mathrm{Ni}$ foam cathode decorated with $\mathrm{NiMoO}_{4} \mathrm{NPs}$ [146] to produce hydrogen at an interesting rate $\left(0.12 \mathrm{~L} \mathrm{H}_{2} \mathrm{~L}^{-1} \mathrm{~d}^{-1}\right)$ in a dual-chamber MEC fed by sugar industry wastewater. In conclusion, there are already many valid examples of metal/metal oxide NPs used in MECs, but systematic efforts aiming to identify a NP synthesis approach that is green, sustainable, and economically feasible should be intensified.

\subsection{Carbon-Sourced Nanomaterials}

Carbon-based nanostructured materials have also been used nowadays for application in the field of MFCs, progressing from their simple use as cheaper non-structured materials. Although carbon-based biomaterials can be used either as anodes or cathodes, usually, the 
oxygen-defective and activated structure of biochar is often used as the cathode material, due to the high cost-share of this component. Biochar products are usually compared with Pt-C loaded carbon papers, cloths, or felts as these are the commercial and reference benchmark materials for cathodes.

Ngaw et al. showed that carbon nanotubes and graphene are very effective materials for use in MFCs [147]. The higher surface areas in graphene sheets and carbon nanotubes facilitate electron transport and thus better effectiveness in MFCs. Sharma et al. showed that carbon nanotubes and E. coli can be used together in MFCs [148]. The incorporation of carbon nanotubes has found the increase in the power density to be in the order of 6 times, i.e., $2470 \mathrm{~mW} \cdot \mathrm{m}^{-2}$ when compared to the $386 \mathrm{~mW} \cdot \mathrm{m}^{-2}$ of control cells. Quantum carbon dots have also been found to enhance MFC performance [149]. The improved performance in power density was $22.5 \%$ with that of the carbon quantum dots. Unfortunately, even if they can preserve catalytic activity [150], these carbon-based nanomaterials are expensive and are not derived from sustainable sources and processes.

Differently from metal/metal oxide NPs, the use of secondary raw material sources, mainly waste biomass, to prepare green and sustainable biochar products is more mature and has been well-reported through the years [151]. Briefly, continuing from Table 1, the performance of biochar materials from various sources is listed in Table 4. The biochar materials were discovered to be useful as self-supported anode electrodes to improve microbial adhesion vs. commercial carbon cloth/felt or as cathode catalyst powders to be dispersed on the cathode support vs. Pt/C commercial catalysts.

Table 4. Comparative performance of biochar materials from biomass as designed for MFC or MEC applications.

\begin{tabular}{|c|c|c|c|c|c|c|}
\hline N. & Source Material & $\begin{array}{c}\text { MFC/MEC } \\
\text { Type }\end{array}$ & Component & 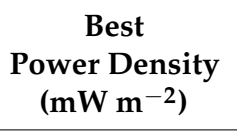 & 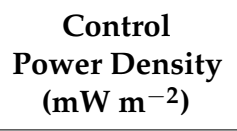 & Ref. \\
\hline 1 & $\begin{array}{c}\text { Water hyacinth } \\
\text { (Eichhornia crassipes) }\end{array}$ & Single chamber & $\begin{array}{l}\text { Cathode } \\
\text { catalyst }\end{array}$ & 12.3 & 24.7 & {$[50]$} \\
\hline 2 & Bananas & Single chamber & $\begin{array}{l}\text { Cathode } \\
\text { catalyst }\end{array}$ & 528.2 & 695 & [51] \\
\hline 3 & Alfalfa leaves & Single chamber & $\begin{array}{l}\text { Cathode } \\
\text { catalyst }\end{array}$ & 1328.9 & 1337.7 & [52] \\
\hline 4 & Corncob & Single chamber & $\begin{array}{l}\text { Cathode } \\
\text { catalyst }\end{array}$ & $458.8 \mathrm{~mW} \mathrm{~m}^{-3}$ & - & [53] \\
\hline 5 & $\begin{array}{l}\text { Green algae } \\
\text { (Spirogyra) }\end{array}$ & Dual chamber & $\begin{array}{l}\text { Anode } \\
\text { electrode }\end{array}$ & $408 \pm 12$ & 62 & [54] \\
\hline 6 & Pinewood lumber & Single chamber & $\begin{array}{l}\text { Cathode } \\
\text { catalyst }\end{array}$ & 146.7 & 156.8 & [55] \\
\hline 7 & Lotus leaves & Single chamber & $\begin{array}{l}\text { Cathode } \\
\text { catalyst }\end{array}$ & $511.5 \pm 25.6$ & $486.7 \pm 23.3$ & [56] \\
\hline 8 & Sewage Sludge & Single chamber & $\begin{array}{l}\text { Cathode } \\
\text { catalyst }\end{array}$ & $500 \pm 17$ & $625 \pm 17$ & [57] \\
\hline 9 & Coffee waste & Single chamber & $\begin{array}{l}\text { Anode } \\
\text { electrode }\end{array}$ & 3927 & 975 & {$[58]$} \\
\hline 10 & Kapok tree fibres & Single chamber & Anode & 1738.1 & 1689.8 & [59] \\
\hline 11 & Eggplant & Single chamber & $\begin{array}{l}\text { Cathode } \\
\text { catalyst }\end{array}$ & 667 & 621 & {$[60]$} \\
\hline 12 & Rice husk & Single chamber & $\begin{array}{l}\text { Cathode } \\
\text { catalyst }\end{array}$ & $317.7 \pm 0.4$ & $367.8 \pm 7.8$ & [61] \\
\hline 13 & Mixed microalgae & Dual chamber & $\begin{array}{l}\text { Cathode } \\
\text { catalyst }\end{array}$ & $\begin{array}{c}12.86 \pm 0.35 \\
W^{-3} m^{-3}\end{array}$ & $\begin{array}{c}13.52 \pm 0.05 \\
W^{-3} m^{-3}\end{array}$ & [62] \\
\hline
\end{tabular}


Table 4. Cont.

\begin{tabular}{|c|c|c|c|c|c|c|}
\hline N. & Source Material & $\begin{array}{c}\text { MFC/MEC } \\
\text { Type }\end{array}$ & Component & $\begin{array}{c}\text { Best } \\
\text { Power Density } \\
\left(\mathrm{mW} \mathrm{m}^{-2}\right)\end{array}$ & 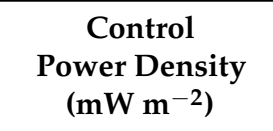 & Ref. \\
\hline 14 & Watermelon rind & Single chamber & $\begin{array}{l}\text { Cathode } \\
\text { catalyst }\end{array}$ & $262 \mathrm{~mW} \mathrm{~m}^{-3}$ & - & [63] \\
\hline 15 & $\begin{array}{c}\text { Sewage } \\
\text { sludge/coconut shell }\end{array}$ & Single chamber & $\begin{array}{l}\text { Anode and } \\
\text { cathode } \\
\text { catalysts }\end{array}$ & $969 \pm 28$ & $1069 \pm 15$ & [64] \\
\hline 16 & $\begin{array}{l}\text { Sludge from } \\
\text { wastewater treatment }\end{array}$ & Single chamber & $\begin{array}{l}\text { Anode } \\
\text { catalyst }\end{array}$ & $\begin{array}{l}\text { (CH } \mathrm{CH}_{4} \text { prod.) } 110 \\
\mathrm{~mL}_{\mathrm{CH} 4} \mathrm{~g}^{-1} \text { VSadded }\end{array}$ & $\begin{array}{c}\left(\mathrm{CH}_{4} \text { prod. }\right) \\
80 \\
\mathrm{~mL}_{\mathrm{CH} 4} \mathrm{~g}^{-1} \text { vSadded }\end{array}$ & [65] \\
\hline 17 & Coconut shell & Dual chamber & $\begin{array}{l}\text { Anode } \\
\text { catalyst }\end{array}$ & $\begin{array}{c}\text { (COD rem.) } \\
71.4 \%\end{array}$ & $\begin{array}{c}\text { (COD rem.) } \\
59.6 \%\end{array}$ & [152] \\
\hline 18 & $\begin{array}{l}\text { Sugar industry filter } \\
\text { cake }\end{array}$ & Dual chamber & $\begin{array}{l}\text { Anode } \\
\text { catalyst }\end{array}$ & $\begin{array}{c}\left.\text { ( } \mathrm{H}_{2} \text { prod. }\right) \\
3.6 \pm 0.4 \\
\mathrm{~mL}_{\mathrm{H} 2} \mathrm{~L}^{-1} \mathrm{~h}^{-1}\end{array}$ & - & [153] \\
\hline 19 & Straw & Dual chamber & $\begin{array}{l}\text { Anode } \\
\text { catalyst }\end{array}$ & $\begin{array}{c}\text { (COD rem.) } \\
87.94 \%\end{array}$ & $\begin{array}{c}\text { (COD rem.) } \\
57.58 \%\end{array}$ & [154] \\
\hline
\end{tabular}

The increase in maximum power density appears to be greater when biochar materials are used as the anode because the cathode catalyst in those studies is usually $\mathrm{Pt}$, and also because the adhesion, growth, and direct interspecies electron transfer (DIET) [155], compared to electron transfer intermediated by dissolved or immobilized mediators $[156,157]$ is greatly enhanced when using biochar, whereas the use of biochar doped with transition metals and nitrogen atoms does not always show a straightforward improvement of power density when compared to a control (e.g., $\mathrm{Pt} / \mathrm{C}$ ) as the main advantage lies in the substitution of $\mathrm{Pt}$ with low-cost catalysts to increase the cost-effectiveness rather than an absolute increase in power production.

Carbon-based composites are widespread in microbial electrochemical devices. For example, Esmaeili et al. showed that biocomposites based on K-carrageenan/polypyrrole could be a better material to be used as a cathode in an MFC [158]. Hernández et al. showed that a PEDOT/nickel/graphene nanocomposite is a better composite for improving the performance of a MFC [159]. In a recent study, $\mathrm{CoO} /$ nitrogen/carbon nanotubebased nanocomposites have been demonstrated to be very effective cathode materials for use in MFCs. A maximal achieved power density of $1260 \mathrm{~mW} \cdot \mathrm{m}^{-2}$ was observed [160]. Many of the biochar materials reported here can conveniently substitute graphene-based supports as they have a sufficient nanostructure, high surface area, active sites, and natural biocompatibility with the pertinent microorganisms. This is a very interesting field for investigation, especially for application in MECs.

\section{Conclusions and Future Development}

The collected and discussed literature demonstrate that many options have been explored to obtain major nanoparticle types by using either natural resources, waste materials, or green processes. This review has been carried out in order to encourage future research studies on these topics by covering the still present lack of literature for some unsolved issues concerning reliability and scalability, rather than proofs of concepts, as such proofs are already solid enough and accepted in the scientific community due to the high number of publications in the field.

The purity, quality, and size of the obtained nanoparticles is often good enough for the target application. Depending on the particular synthesis environment, different sizes and morphologies can be obtained, but the exact control of these parameters needs to be investigated further to unveil the precise mechanisms occurring in these complex 
systems. This is particularly relevant when bacteria are used. Another bottleneck for such biosynthesis is the long time-to-product duration that is required, as sometimes two to three days are required to complete a reaction, apart from the separation and extraction steps. More reproducible and reliable processes are those based on mechanical or physical operations, but they appear to not be sustainable, even if they can recover, harvest, and valorize waste products. The gap for these approaches to reach industrial use is not narrow, and the missing steps seem to be a reliable scaling process for high throughput and the cheap production of valuable nanoparticles, as well as the standardization of sizes and morphologies and target properties like porosity and electrical conductivity, etc.

On the other hand, these types of nanomaterials can be efficiently used in MFCs and MECs with benefits from the point of view of economic feasibility. For example, MFCs containing nanocarbon materials or metal NPs from secondary sources have a potential power density boost ranging from a few hundred to a few thousand $\mathrm{mW} \cdot \mathrm{cm}^{-2}$. This implies that cheap and reliable production and the availability of such sustainable nanomaterials is crucial to propelling both fields further towards industrialization. Even for these devices, solid demonstrations of scaled-up systems that are capable of producing and supplying a sufficient amount of energy (MFC) or the production of convenient valueadded products (MEC) are necessary. Indeed, there is a lack of works dealing with the intense use of biochar materials as bifunctional catalysts (i.e., anode and/or cathode) in MECs, considering that biochar materials have been widely proven to positively interact with biofilms. The progress described so far regarding the basic understanding, synthesis schemes, characterization, and testing of many kinds and types of sources, nanoparticles, and applications is very promising for further development of this field with the aim of a greener and cleaner utilization of material sources and resulting energy production.

Author Contributions: Conceptualization, D.F. and G.K.; methodology, D.F, G.K.; resources, Y.K. and E.-B.C.; writing — original draft preparation, D.F., G.K.; writing—review and editing, Y.K. and E.-B.C.; visualization, D.F.; supervision, Y.K., E.-B.C.; funding acquisition, Y.K. and E.-B.C.; All authors have read and agreed to the published version of the manuscript.

Funding: Domenico Frattini was supported by Brain Pool Program through the National Research Foundation of Korea (NRF) funded by the Ministry of Science and ICT (Grant No. 2017H1D3A1A01013887). E.-B. Cho and Gopalu Karunakaran were supported by Brain Pool Program through the National Research Foundation of Korea (NRF) funded by the Ministry of Science and ICT (Grant No. 2018H1D3A1A01037054). Gopalu Karunakaran also acknowledges supports under the Basic Science Research Program through the National Research Foundation of Korea funded by the Ministry of Education (NRF-2019R1I1A1A01062458).

Institutional Review Board Statement: Not applicable.

Informed Consent Statement: Not applicable.

Data Availability Statement: Not applicable.

Conflicts of Interest: The authors declare no conflict of interest.

\section{References}

1. Santoro, C.; Arbizzani, C.; Erable, B.; Ieropoulos, I. Microbial fuel cells: From fundamentals to applications. A review. J. Power Sources 2017, 356, 225-244. [CrossRef]

2. Liu, H.; Hu, H.; Chignell, J.; Fan, Y. Microbial electrolysis: Novel technology for hydrogen production from biomass. Biofuels 2010, 1, 129-142. [CrossRef]

3. Drendel, G.; Mathews, E.R.; Semenec, L.; Franks, A.E. Microbial Fuel Cells, Related Technologies, and Their Applications. Appl. Sci. 2018, 8, 2384. [CrossRef]

4. Flimban, S.G.A.; Ismail, I.M.I.; Kim, T.; Oh, S.-E. Overview of Recent Advancements in the Microbial Fuel Cell from Fundamentals to Applications: Design, Major Elements, and Scalability. Energies 2019, 12, 3390. [CrossRef]

5. Kadier, A.; Simayi, Y.; Kalil, M.S.; Abdeshahian, P.; Hamid, A.A. A review of the substrates used in microbial electrolysis cells (MECs) for producing sustainable and clean hydrogen gas. Renew. Energy 2014, 71, 466-472. [CrossRef]

6. Gajda, I.; Greenman, J.; Ieropoulos, I.A. Recent advancements in real-world microbial fuel cell applications. Curr. Opin. Electrochem. 2018, 11, 78-83. [CrossRef] [PubMed] 
7. Christwardana, M.; Frattini, D.; Accardo, G.; Yoon, S.P.; Kwon, Y. Early-stage performance evaluation of flowing microbial fuel cells using chemically treated carbon felt and yeast biocatalyst. Appl. Energy 2018, 222, 369-382. [CrossRef]

8. Jannelli, N.; Nastro, R.A.; Cigolotti, V.; Minutillo, M.; Falcucci, G. Low pH, high salinity: Too much for microbial fuel cells? Appl. Energy 2017, 192, 543-550. [CrossRef]

9. Iannaci, A.; Myles, A.; Flinois, T.; Behan, J.A.; Barrière, F.; Scanlan, E.M.; Colavita, P.E. Tailored glycosylated anode surfaces: Addressing the exoelectrogen bacterial community via functional layers for microbial fuel cell applications. Bioelectrochemistry 2020, 136, 107621. [CrossRef] [PubMed]

10. Rinaldi, A.; Mecheri, B.; Garavaglia, V.; Licoccia, S.; Di Nardo, P.; Traversa, E. Engineering materials and biology to boost performance of microbial fuel cells: A critical review. Energy Environ. Sci. 2008, 1, 417. [CrossRef]

11. Bajracharya, S.; Srikanth, S.; Mohanakrishna, G.; Zacharia, R.; Strik, D.P.; Pant, D. Biotransformation of carbon dioxide in bioelectrochemical systems: State of the art and future prospects. J. Power Sources 2017, 356, 256-273. [CrossRef]

12. Pandey, P.; Shinde, V.N.; Deopurkar, R.L.; Kale, S.P.; Patil, S.A.; Pant, D. Recent advances in the use of different substrates in microbial fuel cells toward wastewater treatment and simultaneous energy recovery. Appl. Energy 2016, 168, 706-723. [CrossRef]

13. Christwardana, M.; Frattini, D.; Accardo, G.; Yoon, S.P.; Kwon, Y. Optimization of glucose concentration and glucose/yeast ratio in yeast microbial fuel cell using response surface methodology approach. J. Power Sources 2018, 402, 402-412. [CrossRef]

14. Andriukonis, E.; Celiesiute-Germaniene, R.; Ramanavicius, S.; Viter, R.; Ramanavicius, A. From Microorganism-Based Amperometric Biosensors towards Microbial Fuel Cells. Sensors 2021, 21, 2442. [CrossRef] [PubMed]

15. Ramanavicius, S.; Ramanavicius, A. Conducting Polymers in the Design of Biosensors and Biofuel Cells. Polymers 2020, 13, 49. [CrossRef]

16. Ramanavicius, S.; Ramanavicius, A. Charge Transfer and Biocompatibility Aspects in Conducting Polymer-Based Enzymatic Biosensors and Biofuel Cells. Nanomaterials 2021, 11, 371. [CrossRef] [PubMed]

17. Bocchetta, P.; Frattini, D.; Tagliente, M.; Selleri, F. Electrochemical Deposition of Polypyrrole Nanostructures for Energy Applications: A Review. Curr. Nanosci. 2020, 16, 462-477. [CrossRef]

18. Ramanavicius, S.; Ramanavicius, A. Progress and Insights in the Application of MXenes as New 2D Nano-Materials Suitable for Biosensors and Biofuel Cell Design. Int. J. Mol. Sci. 2020, 21, 9224. [CrossRef] [PubMed]

19. Bocchetta, P.; Frattini, D.; Ghosh, S.; Mohan, A.M.V.; Kumar, Y.; Kwon, Y. Soft Materials for Wearable/Flexible Electrochemical Energy Conversion, Storage, and Biosensor Devices. Materials 2020, 13, 2733. [CrossRef] [PubMed]

20. Gude, V.G. Wastewater treatment in microbial fuel cells-An overview. J. Clean. Prod. 2016, 122, 287-307. [CrossRef]

21. Aiken, D.C.; Curtis, T.P.; Heidrich, E.S. Avenues to the financial viability of microbial electrolysis cells [MEC] for domestic wastewater treatment and hydrogen production. Int. J. Hydrogen Energy 2019, 44, 2426-2434. [CrossRef]

22. Gajda, I.; Stinchcombe, A.; Merino-Jimenez, I.; Pasternak, G.; Sanchez-Herranz, D.; Greenman, J.; Ieropoulos, I.A. Miniaturized ceramic-based microbial fuel cell for efficient power generation from urine and stack development. Front. Energy Res. 2018, 6, 84. [CrossRef] [PubMed]

23. Ghadge, A.N.; Ghangrekar, M.M. Development of low cost ceramic separator using mineral cation exchanger to enhance performance of microbial fuel cells. Electrochim. Acta 2015, 166, 320-328. [CrossRef]

24. Khalili, H.B.; Mohebbi-Kalhori, D.; Afarani, M.S. Microbial fuel cell (MFC) using commercially available unglazed ceramic wares: Low-cost ceramic separators suitable for scale-up. Int. J. Hydrogen Energy 2017, 42, 8233-8241. [CrossRef]

25. Frattini, D.; Accardo, G.; Kwon, Y. Perovskite ceramic membrane separator with improved biofouling resistance for yeast-based microbial fuel cells. J. Memb. Sci. 2020, 599, 117843. [CrossRef]

26. Zhao, C.; Gai, P.; Song, R.; Chen, Y.; Zhang, J.; Zhu, J.-J. Nanostructured material-based biofuel cells: Recent advances and future prospects. Chem. Soc. Rev. 2017, 46, 1545-1564. [CrossRef] [PubMed]

27. ElMekawy, A.; Hegab, H.M.; Losic, D.; Saint, C.P.; Pant, D. Applications of graphene in microbial fuel cells: The gap between promise and reality. Renew. Sustain. Energy Rev. 2017, 72, 1389-1403. [CrossRef]

28. Yang, W.; Kim, K.-Y.; Saikaly, P.E.; Logan, B.E. The impact of new cathode materials relative to baseline performance of microbial fuel cells all with the same architecture and solution chemistry. Energy Environ. Sci. 2017, 10, 1025-1033. [CrossRef]

29. Frattini, D.; Accardo, G.; Ferone, C.; Cioffi, R. Fabrication and characterization of graphite-cement composites for microbial fuel cells applications. Mater. Res. Bull. 2017, 88, 188-199. [CrossRef]

30. HaoYu, E.; Cheng, S.; Scott, K.; Logan, B. Microbial fuel cell performance with non-Pt cathode catalysts. J. Power Sources 2007, 171, 275-281. [CrossRef]

31. Ben Liew, K.; Daud, W.R.W.; Ghasemi, M.; Leong, J.X.; Su Lim, S.; Ismail, M. Non-Pt catalyst as oxygen reduction reaction in microbial fuel cells: A review. Int. J. Hydrogen Energy 2014, 39, 4870-4883. [CrossRef]

32. Duarte, K.D.Z.; Frattini, D.; Kwon, Y. High performance yeast-based microbial fuel cells by surfactant-mediated gold nanoparticles grown atop a carbon felt anode. Appl. Energy 2019, 256, 113912. [CrossRef]

33. Alatraktchi, F.A.; Zhang, Y.; Angelidaki, I. Nanomodification of the electrodes in microbial fuel cell: Impact of nanoparticle density on electricity production and microbial community. Appl. Energy 2014, 116, 216-222. [CrossRef]

34. Trapero, J.R.; Horcajada, L.; Linares, J.J.; Lobato, J. Is microbial fuel cell technology ready? An economic answer towards industrial commercialization. Appl. Energy 2017, 185, 698-707. [CrossRef]

35. Pepè Sciarria, T.; de Oliveira, M.A.C.; Mecheri, B.; D'Epifanio, A.; Goldfarb, J.L.; Adani, F. Metal-free activated biochar as an oxygen reduction reaction catalyst in single chamber microbial fuel cells. J. Power Sources 2020, 462, 228183. [CrossRef] 
36. Strambeanu, N.; Demetrovici, L.; Dragos, D. Natural Sources of Nanoparticles. In Nanoparticles' Promises and Risks; Springer International Publishing: Cham, Switzerland, 2015; pp. 9-19.

37. Guo, H.; Barnard, A.S. Naturally occurring iron oxide nanoparticles: Morphology, surface chemistry and environmental stability. J. Mater. Chem. A 2013, 1, 27-42. [CrossRef]

38. Wu, C.-Y.; Martel, J.; Wong, T.-Y.; Young, D.; Liu, C.-C.; Lin, C.-W.; Young, J.D. Formation and characteristics of biomimetic mineralo-organic particles in natural surface water. Sci. Rep. 2016, 6, 28817. [CrossRef]

39. McGillicuddy, E.; Murray, I.; Kavanagh, S.; Morrison, L.; Fogarty, A.; Cormican, M.; Dockery, P.; Prendergast, M.; Rowan, N.; Morris, D. Silver nanoparticles in the environment: Sources, detection and ecotoxicology. Sci. Total Environ. 2017, 575, 231-246. [CrossRef] [PubMed]

40. Hough, R.M.; Noble, R.R.P.; Reich, M. Natural gold nanoparticles. Ore Geol. Rev. 2011, 42, 55-61. [CrossRef]

41. Terrones, M. Carbon nanotubes: Synthesis and properties, electronic devices and other emerging applications. Int. Mater. Rev. 2004, 49, 325-377. [CrossRef]

42. Faulstich, L.; Griffin, S.; Nasim, M.J.; Masood, M.I.; Ali, W.; Alhamound, S.; Omran, Y.; Kim, H.; Kharma, A.; Schäfer, K.-H.; et al. Nature's Hat-trick: Can we use sulfur springs as ecological source for materials with agricultural and medical applications? Int. Biodeterior. Biodegrad. 2017, 119, 678-686. [CrossRef]

43. Alkadasi, N.A.N. Synthesis of Fe3O4 nanoparticles from Ironstone from The Republic of Yemen. Orient. J. Chem. 2014, 30, 1173-1178. [CrossRef]

44. Manivasakan, P.; Rajendran, V.; Rauta, P.R.; Sahu, B.B.; Sahu, P.; Panda, B.K.; Valiyaveettill, S.; Jegadesan, S. Effect of TiO2 Nanoparticles on Properties of Silica Refractory. J. Am. Ceram. Soc. 2010, 93, 2236-2243. [CrossRef]

45. Manivasakan, P.; Rajendran, V.; Rauta, P.R.; Sahu, B.B.; Panda, B.K. Effect of mineral acids on the production of alumina nanopowder from raw bauxite. Powder Technol. 2011, 211, 77-84. [CrossRef]

46. Raman, D.N.; Rajapandi, V.; Sundaramoorthy, A.; Ravisekaran, S.S.; Annadurai, N. Naturally derived FeTiO3 nanoparticles: Analysis of optical properties. J. Mater. Sci. Mater. Electron. 2020, 31, 16951-16958. [CrossRef]

47. Pan, J.; Ma, J.; Zhai, L.; Luo, T.; Mei, Z.; Liu, H. Achievements of biochar application for enhanced anaerobic digestion: A review. Bioresour. Technol. 2019, 292, 122058. [CrossRef]

48. Li, D.; Zhao, R.; Peng, X.; Ma, Z.; Zhao, Y.; Gong, T.; Sun, M.; Jiao, Y.; Yang, T.; Xi, B. Biochar-related studies from 1999 to 2018: A bibliometrics-based review. Environ. Sci. Pollut. Res. 2020, 27, 2898-2908. [CrossRef]

49. Biochar for Environmental Management; Lehmann, J.; Joseph, S. (Eds.) Routledge: London, UK, 2015 ; ISBN 9781849770552.

50. Allam, F.; Elnouby, M.; El-Khatib, K.M.; El-Badan, D.E.; Sabry, S.A. Water hyacinth (Eichhornia crassipes) biochar as an alternative cathode electrocatalyst in an air-cathode single chamber microbial fuel cell. Int. J. Hydrogen Energy 2020, 45, 5911-5927. [CrossRef]

51. Yuan, H.; Deng, L.; Qi, Y.; Kobayashi, N.; Tang, J. Nonactivated and Activated Biochar Derived from Bananas as Alternative Cathode Catalyst in Microbial Fuel Cells. Sci. World J. 2014, 2014, 832850. [CrossRef] [PubMed]

52. Deng, L.; Yuan, Y.; Zhang, Y.; Wang, Y.; Chen, Y.; Yuan, H.; Chen, Y. Alfalfa Leaf-Derived Porous Heteroatom-Doped Carbon Materials as Efficient Cathodic Catalysts in Microbial Fuel Cells. ACS Sustain. Chem. Eng. 2017, 5, 9766-9773. [CrossRef]

53. Li, M.; Zhang, H.; Xiao, T.; Wang, S.; Zhang, B.; Chen, D.; Su, M.; Tang, J. Low-cost biochar derived from corncob as oxygen reduction catalyst in air cathode microbial fuel cells. Electrochim. Acta 2018, 283, 780-788. [CrossRef]

54. Shi, Y.-T.; Yu, Y.-Y.; Xu, Z.-A.; Lian, J.; Yong, Y.-C. Superior carbon belts from Spirogyra for efficient extracellular electron transfer and sustainable microbial energy harvesting. J. Mater. Chem. A 2019, 7, 6930-6938. [CrossRef]

55. Huggins, T.M.; Pietron, J.J.; Wang, H.; Ren, Z.J.; Biffinger, J.C. Graphitic biochar as a cathode electrocatalyst support for microbial fuel cells. Bioresour. Technol. 2015, 195, 147-153. [CrossRef]

56. Ye, W.; Tang, J.; Wang, Y.; Cai, X.; Liu, H.; Lin, J.; Van der Bruggen, B.; Zhou, S. Hierarchically structured carbon materials derived from lotus leaves as efficient electrocatalyst for microbial energy harvesting. Sci. Total Environ. 2019, 666, 865-874. [CrossRef]

57. Yuan, Y.; Yuan, T.; Wang, D.; Tang, J.; Zhou, S. Sewage sludge biochar as an efficient catalyst for oxygen reduction reaction in an microbial fuel cell. Bioresour. Technol. 2013, 144, 115-120. [CrossRef] [PubMed]

58. Hung, Y.; Liu, T.; Chen, H. Renewable Coffee Waste-Derived Porous Carbons as Anode Materials for High-Performance Sustainable Microbial Fuel Cells. ACS Sustain. Chem. Eng. 2019, 7, 16991-16999. [CrossRef]

59. Zhu, H.; Wang, H.; Li, Y.; Bao, W.; Fang, Z.; Preston, C.; Vaaland, O.; Ren, Z.; Hu, L. Lightweight, conductive hollow fibers from nature as sustainable electrode materials for microbial energy harvesting. Nano Energy 2014, 10, 268-276. [CrossRef]

60. Zha, Z.; Zhang, Z.; Xiang, P.; Zhu, H.; Zhou, B.; Sun, Z.; Zhou, S. One-step preparation of eggplant-derived hierarchical porous graphitic biochar as efficient oxygen reduction catalyst in microbial fuel cells. RSC Adv. 2021, 11, 1077-1085. [CrossRef]

61. Jiao, Y.; Hu, Y.; Han, L.; Zhou, M. Activated Carbon Derived from Rice Husk as Efficient Oxygen Reduction Catalyst in Microbial Fuel Cell. Electroanalysis 2020, 32, 2969-2975. [CrossRef]

62. Chakraborty, I.; Bhowmick, G.D.; Ghosh, D.; Dubey, B.K.; Pradhan, D.; Ghangrekar, M.M. Novel low-cost activated algal biochar as a cathode catalyst for improving performance of microbial fuel cell. Sustain. Energy Technol. Assess. 2020, 42, 100808. [CrossRef]

63. Zhong, K.; Li, M.; Yang, Y.; Zhang, H.; Zhang, B.; Tang, J.; Yan, J.; Su, M.; Yang, Z. Nitrogen-doped biochar derived from watermelon rind as oxygen reduction catalyst in air cathode microbial fuel cells. Appl. Energy 2019, 242, 516-525. [CrossRef]

64. Yuan, Y.; Liu, T.; Fu, P.; Tang, J.; Zhou, S. Conversion of sewage sludge into high-performance bifunctional electrode materials for microbial energy harvesting. J. Mater. Chem. A 2015, 3, 8475-8482. [CrossRef] 
65. Yin, C.; Shen, Y.; Yuan, R.; Zhu, N.; Yuan, H.; Lou, Z. Sludge-based biochar-assisted thermophilic anaerobic digestion of waste-activated sludge in microbial electrolysis cell for methane production. Bioresour. Technol. 2019, 284, 315-324. [CrossRef] [PubMed]

66. Chaves Fernandes, B.C.; Ferreira Mendes, K.; Dias Júnior, A.F.; da Silva Caldeira, V.P.; da Silva Teófilo, T.M.; Severo Silva, T.; Mendonça, V.; de Freitas Souza, M.; Valadão Silva, D. Impact of Pyrolysis Temperature on the Properties of Eucalyptus Wood-Derived Biochar. Materials 2020, 13, 5841. [CrossRef]

67. Varma, R.S. Greener approach to nanomaterials and their sustainable applications. Curr. Opin. Chem. Eng. 2012, 1, 123-128. [CrossRef]

68. Abdelghany, T.M.; Al-Rajhi, A.M.H.; Al Abboud, M.A.; Alawlaqi, M.M.; Ganash Magdah, A.; Helmy, E.A.M.; Mabrouk, A.S. Recent Advances in Green Synthesis of Silver Nanoparticles and Their Applications: About Future Directions. A Review. Bionanoscience 2018, 8, 5-16. [CrossRef]

69. Hebbalalu, D.; Lalley, J.; Nadagouda, M.N.; Varma, R.S. Greener Techniques for the Synthesis of Silver Nanoparticles Using Plant Extracts, Enzymes, Bacteria, Biodegradable Polymers, and Microwaves. ACS Sustain. Chem. Eng. 2013, 1, 703-712. [CrossRef]

70. Uma Suganya, K.S.; Govindaraju, K.; Ganesh Kumar, V.; Stalin Dhas, T.; Karthick, V.; Singaravelu, G.; Elanchezhiyan, M. Blue green alga mediated synthesis of gold nanoparticles and its antibacterial efficacy against Gram positive organisms. Mater. Sci. Eng. C 2015, 47, 351-356. [CrossRef] [PubMed]

71. Kou, J.; Varma, R.S. Beet juice utilization: Expeditious green synthesis of noble metal nanoparticles (Ag, Au, Pt, and Pd) using microwaves. RSC Adv. 2012, 2, 10283. [CrossRef]

72. Gholami-Shabani, M.; Shams-Ghahfarokhi, M.; Gholami-Shabani, Z.; Akbarzadeh, A.; Riazi, G.; Ajdari, S.; Amani, A.; RazzaghiAbyaneh, M. Enzymatic synthesis of gold nanoparticles using sulfite reductase purified from Escherichia coli: A green eco-friendly approach. Process Biochem. 2015, 50, 1076-1085. [CrossRef]

73. Adelere, I.A.; Lateef, A. A novel approach to the green synthesis of metallic nanoparticles: The use of agro-wastes, enzymes, and pigments. Nanotechnol. Rev. 2016, 5. [CrossRef]

74. Sunkar, S.; Nachiyar, C.V. Biogenesis of antibacterial silver nanoparticles using the endophytic bacterium Bacillus cereus isolated from Garcinia xanthochymus. Asian Pac. J. Trop. Biomed. 2012, 2, 953-959. [CrossRef]

75. Deplanche, K.; Macaskie, L.E. Biorecovery of gold by Escherichia coli and Desulfovibrio desulfuricans. Biotechnol. Bioeng. 2008, 99, 1055-1064. [CrossRef]

76. Mann, S.; Frankel, R.B.; Blakemore, R.P. Structure, morphology and crystal growth of bacterial magnetite. Nature 1984, 310, 405-407. [CrossRef]

77. Marshall, M.J.; Beliaev, A.S.; Dohnalkova, A.C.; Kennedy, D.W.; Shi, L.; Wang, Z.; Boyanov, M.I.; Lai, B.; Kemner, K.M.; McLean, J.S.; et al. c-Type Cytochrome-Dependent Formation of U(IV) Nanoparticles by Shewanella oneidensis. PLoS Biol. 2006, 4, e268. [CrossRef] [PubMed]

78. Chen, Y.-L.; Tuan, H.-Y.; Tien, C.-W.; Lo, W.-H.; Liang, H.-C.; Hu, Y.-C. Augmented biosynthesis of cadmium sulfide nanoparticles by genetically engineered Escherichia coli. Biotechnol. Progr. 2009, 25, 1260-1266. [CrossRef] [PubMed]

79. Ravindra, B.K.; Rajasab, A.H. A comparative study on biosynthesis of silver nanoparticles using four different fungal species. Int. J. Pharm. Pharm. Sci. 2014, 6, 372-376.

80. Gericke, M.; Pinches, A. Microbial production of gold nanoparticles. Gold Bull. 2006, 39, 22-28. [CrossRef]

81. Senapati, S.; Ahmad, A.; Khan, M.I.; Sastry, M.; Kumar, R. Extracellular Biosynthesis of Bimetallic Au-Ag Alloy Nanoparticles. Small 2005, 1, 517-520. [CrossRef] [PubMed]

82. Raliya, R.; Tarafdar, J.C. Biosynthesis and characterization of zinc, magnesium and titanium nanoparticles: An eco-friendly approach. Int. Nano Lett. 2014, 4, 93. [CrossRef]

83. Raliya, R.; Biswas, P.; Tarafdar, J.C. TiO2 nanoparticle biosynthesis and its physiological effect on mung bean (Vigna radiata L.). Biotechnol. Rep. 2015, 5, 22-26. [CrossRef]

84. Krishnaraj, C.; Jagan, E.G.; Rajasekar, S.; Selvakumar, P.; Kalaichelvan, P.T.; Mohan, N. Synthesis of silver nanoparticles using Acalypha indica leaf extracts and its antibacterial activity against water borne pathogens. Coll. Surf. B Biointerfaces 2010, 76, 50-56. [CrossRef]

85. Armendariz, V.; Herrera, I.; Peralta-videa, J.R.; Jose-yacaman, M.; Troiani, H.; Santiago, P.; Gardea-Torresdey, J.L. Size controlled gold nanoparticle formation by Avena sativa biomass: Use of plants in nanobiotechnology. J. Nanoparticle Res. 2004, 6, 377-382. [CrossRef]

86. Jia, L.; Zhang, Q.; Li, Q.; Song, H. The biosynthesis of palladium nanoparticles by antioxidants in Gardenia jasminoides Ellis: Long lifetime nanocatalysts for p-nitrotoluene hydrogenation. Nanotechnology 2009, 20, 385601. [CrossRef]

87. Herrera-Becerra, R.; Zorrilla, C.; Rius, J.L.; Ascencio, J.A. Electron microscopy characterization of biosynthesized iron oxide nanoparticles. Appl. Phys. A 2008, 91, 241-246. [CrossRef]

88. Qu, J.; Luo, C.; Hou, J. Synthesis of ZnO nanoparticles from Zn-hyperaccumulator (Sedum alfredii Hance) plants. Micro Nano Lett. 2011, 6, 174. [CrossRef]

89. Maensiri, S.; Laokul, P.; Klinkaewnarong, J.; Phokha, S.; Promarak, V.; Seraphin, S. Indium oxide (In2O3) nanoparticles using Aloe vera plant extract: Synthesis and optical properties. J. Optoelectron. Adv. Mater. 2008, 10, 161-165. 
90. Kisieliute, A.; Popov, A.; Apetrei, R.-M.; Cârâc, G.; Morkvenaite-Vilkonciene, I.; Ramanaviciene, A.; Ramanavicius, A. Towards microbial biofuel cells: Improvement of charge transfer by self-modification of microoganisms with conducting polymerPolypyrrole. Chem. Eng. J. 2019, 356, 1014-1021. [CrossRef]

91. Ramanavicius, A.; Ramanaviciene, A. Hemoproteins in Design of Biofuel Cells. Fuel Cells 2009, 9, 25-36. [CrossRef]

92. Andriukonis, E.; Stirke, A.; Garbaras, A.; Mikoliunaite, L.; Ramanaviciene, A.; Remeikis, V.; Thornton, B.; Ramanavicius, A. Yeast-assisted synthesis of polypyrrole: Quantification and influence on the mechanical properties of the cell wall. Coll. Surf. B Biointerfaces 2018, 164, 224-231. [CrossRef] [PubMed]

93. Ramanavicius, A.; Andriukonis, E.; Stirke, A.; Mikoliunaite, L.; Balevicius, Z.; Ramanaviciene, A. Synthesis of polypyrrole within the cell wall of yeast by redox-cycling of $\left[\mathrm{Fe}(\mathrm{CN})_{6}\right]^{3-} /\left[\mathrm{Fe}(\mathrm{CN})_{6}\right]^{4-}$. Enzyme Microb. Technol. 2016, 83, 40-47. [CrossRef]

94. Stirke, A.; Apetrei, R.-M.; Kirsnyte, M.; Dedelaite, L.; Bondarenka, V.; Jasulaitiene, V.; Pucetaite, M.; Selskis, A.; Carac, G.; Bahrim, G.; et al. Synthesis of polypyrrole microspheres by Streptomyces spp. Polymer 2016, 84, 99-106. [CrossRef]

95. Apetrei, R.-M.; Carac, G.; Bahrim, G.; Ramanaviciene, A.; Ramanavicius, A. Modification of Aspergillus niger by conducting polymer, Polypyrrole, and the evaluation of electrochemical properties of modified cells. Bioelectrochemistry 2018, 121, 46-55. [CrossRef]

96. Apetrei, R.-M.; Carac, G.; Ramanaviciene, A.; Bahrim, G.; Tanase, C.; Ramanavicius, A. Cell-assisted synthesis of conducting polymer-Polypyrrole-For the improvement of electric charge transfer through fungal cell wall. Coll. Surf. B Biointerfaces 2019, 175, 671-679. [CrossRef]

97. United Nations. Solid Waste Management. Available online: https://www.unenvironment.org/explore-topics/resourceefficiency / what-we-do/cities / solid-waste-management (accessed on 30 November 2020).

98. Abdelbasir, S.M.; McCourt, K.M.; Lee, C.M.; Vanegas, D.C. Waste-Derived Nanoparticles: Synthesis Approaches, Environmental Applications, and Sustainability Considerations. Front. Chem. 2020, 8. [CrossRef] [PubMed]

99. Xiu, F.-R.; Zhang, F.-S. Size-controlled preparation of $\mathrm{Cu}_{2} \mathrm{O}$ nanoparticles from waste printed circuit boards by supercritical water combined with electrokinetic process. J. Hazard. Mater. 2012, 233-234, 200-206. [CrossRef] [PubMed]

100. Singh, J.; Lee, B.-K. Recovery of precious metals from low-grade automobile shredder residue: A novel approach for the recovery of nanozero-valent copper particles. Waste Manag. 2016, 48, 353-365. [CrossRef]

101. Mdlovu, N.V.; Chiang, C.-L.; Lin, K.-S.; Jeng, R.-C. Recycling copper nanoparticles from printed circuit board waste etchants via a microemulsion process. J. Clean. Prod. 2018, 185, 781-796. [CrossRef]

102. Shokri, A.; Pahlevani, F.; Levick, K.; Cole, I.; Sahajwalla, V. Synthesis of copper-tin nanoparticles from old computer printed circuit boards. J. Clean. Prod. 2017, 142, 2586-2592. [CrossRef]

103. Elsayed, D.M.; Abdelbasir, S.M.; Abdel-Ghafar, H.M.; Salah, B.A.; Sayed, S.A. Silver and copper nanostructured particles recovered from metalized plastic waste for antibacterial applications. J. Environ. Chem. Eng. 2020, 8, 103826. [CrossRef]

104. El-Amir, A.A.M.; Ewais, E.M.M.; Abdel-Aziem, A.R.; Ahmed, A.; El-Anadouli, B.E.H. Nano-alumina powders/ceramics derived from aluminum foil waste at low temperature for various industrial applications. J. Environ. Manag. 2016, 183, 121-125. [CrossRef]

105. Li, X.; Wang, C.; Zeng, Y.; Li, P.; Xie, T.; Zhang, Y. Bacteria-assisted preparation of nano $\alpha$-Fe2O3 red pigment powders from waste ferrous sulfate. J. Hazard. Mater. 2016, 317, 563-569. [CrossRef] [PubMed]

106. Zhou, H.; Su, M.; Lee, P.-H.; Shih, K. Synthesis of submicron lead oxide particles from the simulated spent lead paste for battery anodes. J. Alloys Compd. 2017, 690, 101-107. [CrossRef]

107. Xiang, X.; Xia, F.; Zhan, L.; Xie, B. Preparation of zinc nano structured particles from spent zinc manganese batteries by vacuum separation and inert gas condensation. Sep. Purif. Technol. 2015, 142, 227-233. [CrossRef]

108. Duarte, K.D.Z.; Kwon, Y. In situ carbon felt anode modification via codeveloping Saccharomyces cerevisiae living-template titanium dioxide nanoclusters in a yeast-based microbial fuel cell. J. Power Sources 2020, 474, 228651. [CrossRef]

109. Duarte, K.D.Z.; Kwon, Y. Enhanced extracellular electron transfer of yeast-based microbial fuel cells via one pot substrate-bound growth iron-manganese oxide nanoflowers. J. Power Sources 2020, 474, 228496. [CrossRef]

110. Yang, S.; Chung, Y.; Lee, K.-S.; Kwon, Y. Enhancements in catalytic activity and duration of PdFe bimetallic catalysts and their use in direct formic acid fuel cells. J. Ind. Eng. Chem. 2020, 90, 351-357. [CrossRef]

111. Costa de Oliveira, M.A.; D'Epifanio, A.; Ohnuki, H.; Mecheri, B. Platinum Group Metal-Free Catalysts for Oxygen Reduction Reaction: Applications in Microbial Fuel Cells. Catalysts 2020, 10, 475. [CrossRef]

112. Zhao, N.; Liang, D.; Meng, S.; Li, X. Bibliometric and content analysis on emerging technologies of hydrogen production using microbial electrolysis cells. Int. J. Hydrogen Energy 2020, 45, 33310-33324. [CrossRef]

113. Kim, C.; Kim, J.R.; Heo, J. Enhancement of bioelectricity generation by a microbial fuel cell using Ti nanoparticle-modified carbon electrode. J. Chem. Technol. Biotechnol. 2019, 94, 1622-1627. [CrossRef]

114. Wu, X.; Xiong, X.; Owens, G.; Brunetti, G.; Zhou, J.; Yong, X.; Xie, X.; Zhang, L.; Wei, P.; Jia, H. Anode modification by biogenic gold nanoparticles for the improved performance of microbial fuel cells and microbial community shift. Bioresour. Technol. 2018, 270, 11-19. [CrossRef]

115. Stephen, A.J.; Rees, N.V.; Mikheenko, I.; Macaskie, L.E. Platinum and Palladium Bio-Synthesized Nanoparticles as Sustainable Fuel Cell Catalysts. Front. Energy Res. 2019, 7, 66. [CrossRef]

116. Saravanakumar, K.; MubarakAli, D.; Kathiresan, K.; Thajuddin, N.; Alharbi, N.S.; Chen, J. Biogenic metallic nanoparticles as catalyst for bioelectricity production: A novel approach in microbial fuel cells. Mater. Sci. Eng. B 2016, 203, 27-34. [CrossRef] 
117. Harshiny, M.; Samsudeen, N.; Kameswara, R.J.; Matheswaran, M. Biosynthesized FeO nanoparticles coated carbon anode for improving the performance of microbial fuel cell. Int. J. Hydrogen Energy 2017, 42, 26488-26495. [CrossRef]

118. Xiao, X.; Wang, Q.; Jin, X.; Chen, Z. The Effects of Nanoscale Zerovalent Iron on Microbial Fuel Cells in the Start-up Process. Adv. Sustain. Syst. 2018, 2, 1700181. [CrossRef]

119. Matsena, M.T.; Tichapondwa, S.M.; Chirwa, E.M.N. Synthesis of Biogenic Palladium Nanoparticles Using Citrobacter sp. for Application as Anode Electrocatalyst in a Microbial Fuel Cell. Catalysts 2020, 10, 838. [CrossRef]

120. Tahernia, M.; Mohammadifar, M.; Feng, S.; Choi, S. Biogenic Palladium Nanoparticles for Improving Bioelectricity Generation in Microbial Fuel Cells. In Proceedings of the 2020 IEEE 33rd International Conference on Micro Electro Mechanical Systems (MEMS), Vancouver, BC, Canada, 18-22 January 2020; pp. 425-428.

121. Karim, M.R.; Han, T.H.; Sawant, S.Y.; Shim, J.; Lee, M.Y.; Kim, W.K.; Kim, J.S.; Cho, M.H. Microbial fuel cell-assisted biogenic synthesis of gold nanoparticles and its application to energy production and hydrogen peroxide detection. Korean J. Chem. Eng. 2020, 37, 1241-1250. [CrossRef]

122. Mateo, S.; Cañizares, P.; Rodrigo, M.A.; Fernandez-Morales, F.J. Driving force of the better performance of metal-doped carbonaceous anodes in microbial fuel cells. Appl. Energy 2018, 225, 52-59. [CrossRef]

123. Quan, X.; Sun, B.; Xu, H. Anode decoration with biogenic Pd nanoparticles improved power generation in microbial fuel cells. Electrochim. Acta 2015, 182, 815-820. [CrossRef]

124. Lefebvre, O.; Tan, Z.; Shen, Y.; Ng, H.Y. Optimization of a microbial fuel cell for wastewater treatment using recycled scrap metals as a cost-effective cathode material. Bioresour. Technol. 2013, 127, 158-164. [CrossRef]

125. Xu, H.; Quan, X.; Xiao, Z.; Chen, L. Effect of anodes decoration with metal and metal oxides nanoparticles on pharmaceutically active compounds removal and power generation in microbial fuel cells. Chem. Eng. J. 2018, 335, 539-547. [CrossRef]

126. Liu, J.; Vipulanandan, C. Effects of Fe, Ni, and Fe/Ni metallic nanoparticles on power production and biosurfactant production from used vegetable oil in the anode chamber of a microbial fuel cell. Waste Manag. 2017, 66, 169-177. [CrossRef] [PubMed]

127. Ayyaru, S.; Mahalingam, S.; Ahn, Y.H. A non-noble $\mathrm{V}_{2} \mathrm{O}_{5}$ nanorods as an alternative cathode catalyst for microbial fuel cell applications. Int. J. Hydrogen Energy 2019, 44, 4974-4984. [CrossRef]

128. Guo, W.; Pi, Y.; Song, H.; Tang, W.; Sun, J. Layer-by-layer assembled gold nanoparticles modified anode and its application in microbial fuel cells. Coll. Surf. A Physicochem. Eng. Asp. 2012, 415, 105-111. [CrossRef]

129. Liu, X.W.; Sun, X.F.; Huang, Y.X.; Sheng, G.P.; Zhou, K.; Zeng, R.J.; Dong, F.; Wang, S.G.; Xu, A.W.; Tong, Z.H.; et al. Nanostructured manganese oxide as a cathodic catalyst for enhanced oxygen reduction in a microbial fuel cell fed with a synthetic wastewater. Water Res. 2010, 44, 5298-5305. [CrossRef]

130. Varanasi, J.L.; Nayak, A.K.; Sohn, Y.; Pradhan, D.; Das, D. Improvement of power generation of microbial fuel cell by integrating tungsten oxide electrocatalyst with pure or mixed culture biocatalysts. Electrochim. Acta 2016, 199, 154-163. [CrossRef]

131. Fan, Y.; Xu, S.; Schaller, R.; Jiao, J.; Chaplen, F.; Liu, H. Nanoparticle decorated anodes for enhanced current generation in microbial electrochemical cells. Biosens. Bioelectron. 2011, 26, 1908-1912. [CrossRef]

132. Heydorn, R.L.; Engel, C.; Krull, R.; Dohnt, K. Strategies for the Targeted Improvement of Anodic Electron Transfer in Microbial Fuel Cells. ChemBioEng Rev. 2020, 7, 4-17. [CrossRef]

133. Heydorn, R.L.; Engel, C.; Krull, R.; Dohnt, K. Strategien zur gezielten Verbesserung des anodenseitigen Elektronentransfers in mikrobiellen Brennstoffzellen. Chem. Ing. Tech. 2019, 91, 744-757. [CrossRef]

134. Qiao, Y.; Bao, S.-J.; Li, C.M.; Cui, X.-Q.; Lu, Z.-S.; Guo, J. Nanostructured Polyaniline/Titanium Dioxide Composite Anode for Microbial Fuel Cells. ACS Nano 2008, 2, 113-119. [CrossRef]

135. Ma, M.; Dai, Y.; Zou, J.; Wang, L.; Pan, K.; Fu, H. Synthesis of Iron Oxide/Partly Graphitized Carbon Composites as a HighEfficiency and Low-Cost Cathode Catalyst for Microbial Fuel Cells. ACS Appl. Mater. Interfaces 2014, 6, 13438-13447. [CrossRef]

136. Di Palma, L.; Bavasso, I.; Sarasini, F.; Tirillò, J.; Puglia, D.; Dominici, F.; Torre, L. Synthesis, characterization and performance evaluation of Fe3O4/PES nano composite membranes for microbial fuel cell. Eur. Polym. J. 2018, 99, 222-229. [CrossRef]

137. Huang, Y.X.; Liu, X.W.; Sun, X.F.; Sheng, G.P.; Zhang, Y.Y.; Yan, G.M.; Wang, S.G.; Xu, A.W.; Yu, H.Q. A new cathodic electrode deposit with palladium nanoparticles for cost-effective hydrogen production in a microbial electrolysis cell. Int. J. Hydrogen Energy 2011, 36, 2773-2776. [CrossRef]

138. Hennebel, T.; Benner, J.; Clauwaert, P.; Vanhaecke, L.; Aelterman, P.; Callebaut, R.; Boon, N.; Verstraete, W. Dehalogenation of environmental pollutants in microbial electrolysis cells with biogenic palladium nanoparticles. Biotechnol. Lett. 2011, 33, 89-95. [CrossRef] [PubMed]

139. Xiao, L.; Wen, Z.; Ci, S.; Chen, J.; He, Z. Carbon/iron-based nanorod catalysts for hydrogen production in microbial electrolysis cells. Nano Energy 2012, 1, 751-756. [CrossRef]

140. Kim, J.H.; Kim, C.; Jeon, Y.; Kim, S. Hydrogen Production from Makgeolli Wastewater Using a Single-Chamber Microbial Electrolysis Cell. Bull. Korean Chem. Soc. 2019, 12-14. [CrossRef]

141. Choi, M.J.; Yang, E.; Yu, H.W.; Kim, I.S.; Oh, S.E.; Chae, K.J. Transition metal/carbon nanoparticle composite catalysts as platinum substitutes for bioelectrochemical hydrogen production using microbial electrolysis cells. Int. J. Hydrogen Energy 2019, 44, 2258-2265. [CrossRef]

142. Wang, W.; Zhang, B.; He, Z. Bioelectrochemical deposition of palladium nanoparticles as catalysts by Shewanella oneidensis MR-1 towards enhanced hydrogen production in microbial electrolysis cells. Electrochim. Acta 2019, 318, 794-800. [CrossRef] 
143. Zakaria, B.S.; Barua, S.; Sharaf, A.; Liu, Y.; Dhar, B.R. Impact of antimicrobial silver nanoparticles on anode respiring bacteria in a microbial electrolysis cell. Chemosphere 2018, 213, 259-267. [CrossRef]

144. Hu, J.; Zeng, C.; Liu, G.; Luo, H.; Qu, L.; Zhang, R. Magnetite nanoparticles accelerate the autotrophic sulfate reduction in biocathode microbial electrolysis cells. Biochem. Eng. J. 2018, 133, 96-105. [CrossRef]

145. Yuan, H.; Deng, L.; Cai, X.; Zheng, T.; Zhou, S.; Chen, Y.; Yuan, Y. Recycling electroplating sludge to produce sustainable electrocatalysts for the efficient conversion of carbon dioxide in a microbial electrolysis cell. Electrochim. Acta 2016, 222, 177-184. [CrossRef]

146. Jayabalan, T.; Matheswaran, M.; Radhakrishnan, T.K.; Naina Mohamed, S. Influence of Nickel molybdate nanocatalyst for enhancing biohydrogen production in microbial electrolysis cell utilizing sugar industrial effluent. Bioresour. Technol. 2021, 320, 124284. [CrossRef]

147. Ngaw, C.K.; Zhao, C.; Wang, V.B.; Kjelleberg, S.; Yang Tan, T.T.; Zhang, Q.; Joachim Loo, S.C. A graphene/carbon nanotube biofilm based solar-microbial fuel device for enhanced hydrogen generation. Sustain. Energy Fuels 2017, 1, 191-198. [CrossRef]

148. Sharma, T.; Mohanareddy, A.; Chandra, T.; Ramaprabhu, S. Development of carbon nanotubes and nanofluids based microbial fuel cell. Int. J. Hydrogen Energy 2008, 33, 6749-6754. [CrossRef]

149. Vishwanathan, A.S.; Aiyer, K.S.; Chunduri, L.A.A.; Venkataramaniah, K.; Siva Sankara Sai, S.; Rao, G. Carbon quantum dots shuttle electrons to the anode of a microbial fuel cell. 3 Biotech 2016, 6, 228. [CrossRef]

150. Christwardana, M.; Kwon, Y. Yeast and carbon nanotube based biocatalyst developed by synergetic effects of covalent bonding and hydrophobic interaction for performance enhancement of membraneless microbial fuel cell. Bioresour. Technol. 2017, 225, 175-182. [CrossRef]

151. Chakraborty, I.; Sathe, S.M.; Dubey, B.K.; Ghangrekar, M.M. Waste-derived biochar: Applications and future perspective in microbial fuel cells. Bioresour. Technol. 2020, 312, 123587. [CrossRef]

152. Shen, R.; Zhao, L.; Yao, Z.; Feng, J.; Jing, Y.; Watson, J. Efficient Treatment of Wood Vinegar via Microbial Electrolysis Cell with the Anode of Different Pyrolysis Biochars. Front. Energy Res. 2020, 8, 1-12. [CrossRef]

153. Keruthiga, K.; Mohamed, S.N.; Gandhi, N.N.; Muthukumar, K. Sugar industry waste-derived anode for enhanced biohydrogen production from rice mill wastewater using artificial photo-assisted microbial electrolysis cell. Int. J. Hydrogen Energy 2021. [CrossRef]

154. Jiang, B.; Zeng, Q.; Liu, J.; Hou, Y.; Xu, J.; Li, H.; Shi, S.; Ma, F. Enhanced treatment performance of phenol wastewater and membrane antifouling by biochar-assisted EMBR. Bioresour. Technol. 2020, 306, 123147. [CrossRef]

155. Chen, S.; Rotaru, A.-E.; Shrestha, P.M.; Malvankar, N.S.; Liu, F.; Fan, W.; Nevin, K.P.; Lovley, D.R. Promoting Interspecies Electron Transfer with Biochar. Sci. Rep. 2015, 4, 5019. [CrossRef] [PubMed]

156. Christwardana, M.; Frattini, D.; Duarte, K.D.Z.; Accardo, G.; Kwon, Y. Carbon felt molecular modification and biofilm augmentation via quorum sensing approach in yeast-based microbial fuel cells. Appl. Energy 2019, 238, 239-248. [CrossRef]

157. Christwardana, M.; Frattini, D.; Accardo, G.; Yoon, S.P.; Kwon, Y. Effects of methylene blue and methyl red mediators on performance of yeast based microbial fuel cells adopting polyethylenimine coated carbon felt as anode. J. Power Sources 2018, 396, 1-11. [CrossRef]

158. Esmaeili, C.; Ghasemi, M.; Heng, L.Y.; Hassan, S.H.A.; Abdi, M.M.; Daud, W.R.W.; Ilbeygi, H.; Ismail, A.F. Synthesis and application of polypyrrole/carrageenan nano-bio composite as a cathode catalyst in microbial fuel cells. Carbohydr. Polym. 2014, 114, 253-259. [CrossRef]

159. Hernández, L.A.; Riveros, G.; González, D.M.; Gacitua, M.; del Valle, M.A. PEDOT/graphene/nickel-nanoparticles composites as electrodes for microbial fuel cells. J. Mater. Sci. Mater. Electron. 2019, 30, 12001-12011. [CrossRef]

160. Yang, W.; Lu, J.E.; Zhang, Y.; Peng, Y.; Mercado, R.; Li, J.; Zhu, X.; Chen, S. Cobalt oxides nanoparticles supported on nitrogendoped carbon nanotubes as high-efficiency cathode catalysts for microbial fuel cells. Inorg. Chem. Commun. 2019, 105, 69-75. [CrossRef] 